\title{
Taphonomy of mammalian fossil bones from the debris-flow deposits of Somosaguas-North (Middle Miocene, Madrid Basin, Spain)
}

\author{
M. Soledad Domingo a,*, David Martín-Perea a ${ }^{\text {, Laura Domingo }}{ }^{\text {a,b,c }}$, Enrique Cantero ${ }^{\text {d }}$, Juan L. Cantalapiedra ${ }^{\mathrm{e}}$, \\ Blanca A. García Yelo ${ }^{\mathrm{d}}$, Ana Rosa Gómez Cano ${ }^{\mathrm{a}}$, Gema M. Alcalde ${ }^{\mathrm{f}}$, \\ Omid Fesharaki a , Manuel Hernández Fernández ${ }^{\mathrm{a}, \mathrm{b}}$
}

a Departamento de Paleontología, Facultad de Ciencias Geológicas, Universidad Complutense de Madrid, C/ José Antonio Novais 12, 28040 Madrid, Spain

b Departamento de Geología Sedimentaria y Cambio Medioambiental, Instituto de Geociencias (UCM, CSIC), C/ José Antonio Novais 12,28040 Madrid, Spain

c Earth and Planetary Sciences Department, University of California Santa Cruz, 1156 High Street, CA 95064, USA

d Departamento de Paleobiología, Museo Nacional de Ciencias Naturales-CSIC, C/ José Gutiérrez Abascal 2, 28006 Madrid, Spain

e Museum für Naturkunde, Leibniz-Institut für Evolutions und Biodiversitätsforschung, Invalidenstraße 43, 10115 Berlin, Germany

${ }^{\mathrm{f}}$ Avenida Real 26, 28032 Madrid, Spain

\section{A R T I C L E I N F O}

\section{Article history:}

Received 8 March 2016

Received in revised form 13 October 2016

Accepted 19 October 2016

Available online 21 October 2016

\section{Keywords:}

Taphonomy

Aragonian

Miocene

Debris flow

Mammals

Southern Europe

\begin{abstract}
A B S T R A C T
Debris-flow hosted assemblages dominated by mammalian remains are very scarce in the fossil record and few examples are reported. Herein we present a detailed taphonomic study of Somosaguas-North (Madrid Basin, Spain), a Middle Miocene mammalian-dominated site embedded in debris-flow deposits, in order to increase our knowledge of the mode of formation of fossiliferous assemblages in this depositional context. The assemblage includes 6592 large-mammal remains belonging to at least 10 different species. Fossils are found in matrix-supported, poorly-sorted coarse arkosic sandstones and fine conglomerates, which are interpreted as the result of successive debris-flow deposits. Breakage constitutes a pervasive taphonomic alteration in the bone assemblage; however, together with unidentifiable bone fragments, we also found complete to almost complete skeletal elements. Bone remains are isolated, a fact that is indicative of a time of exposure of the carcasses long enough to enable decay and complete disarticulation. There are no associations of elements belonging to the same individual, which suggests that, prior to or during debris-flow transport, bones were profusely dispersed. Based on the taphonomic evidence, we suggest that Somosaguas-North assemblage was formed by successive debris-flow transport and burial of pre-existing thanatocoenoses. Bones from those thanatocoenoses were modified by biostratinomic agents (trampling, weathering) in varying degrees depending on their time of exposure. Debris-flow transport produced further abrasion and breakage in collagen-depleted bones. Our results are congruent with an environmental context of semiarid landscapes presenting long arid periods and highly irregular hydrological seasonality. Finally, we compared the Somosaguas-North assemblage with other debris-flow hosted vertebrate assemblages. Although Somosaguas-North shares taphonomic features with some of these sites, it is not possible to define consistent and single taphonomic patterns for debris-flow assemblages, given the varied taphonomic histories of the remains prior to and during debris-flow transport.
\end{abstract}

(c) 2016 Elsevier B.V. All rights reserved.

\section{Introduction}

The Cenozoic Madrid Basin (Spain) (Fig. 1) contains very abundant continental fossiliferous deposits to the extent that much of our knowledge of the Spanish mammalian faunas dated in the MN5

\footnotetext{
* Corresponding author.

E-mail addresses: soldomingo@gmail.com (M.S. Domingo), davidmam@ucm.es (D. Martín-Perea), ldomingo@ucm.es (L. Domingo), canteroycantero@hotmail.com (E. Cantero), jlopezcant@gmail.com (J.L. Cantalapiedra), blancayelo@hotmail.com (B.A. García Yelo), argomezcano@gmail.com (A.R. Gómez Cano), paleogem@gmail.com (G.M. Alcalde), omidfesh@ucm.es (O. Fesharaki), hdezfdez@ucm.es (M. Hernández Fernández).
}

biochronological unit (Mammal Neogene units, Mein (1975); Middle Aragonian, Middle Miocene) derives from this basin (Alberdi, 1985; Peláez-Campomanes et al., 2003; Hernández-Ballarín et al., 2011; Domingo L. et al., 2012a). Despite the richness of sites, the wealth of studies on the systematics of the faunas and the good control of the geological context, taphonomic studies of the Madrid Basin mammalian sites are very scarce (but see Domingo et al., 2013). In many cases, comprehensive taphonomic studies have been hindered by the fact that many of these localities are found within the limits of the city of Madrid and in the context of public works, and fossils therefore have to be extracted as fast as possible and there is little chance of continuing excavations once public works are completed and sites are covered up 

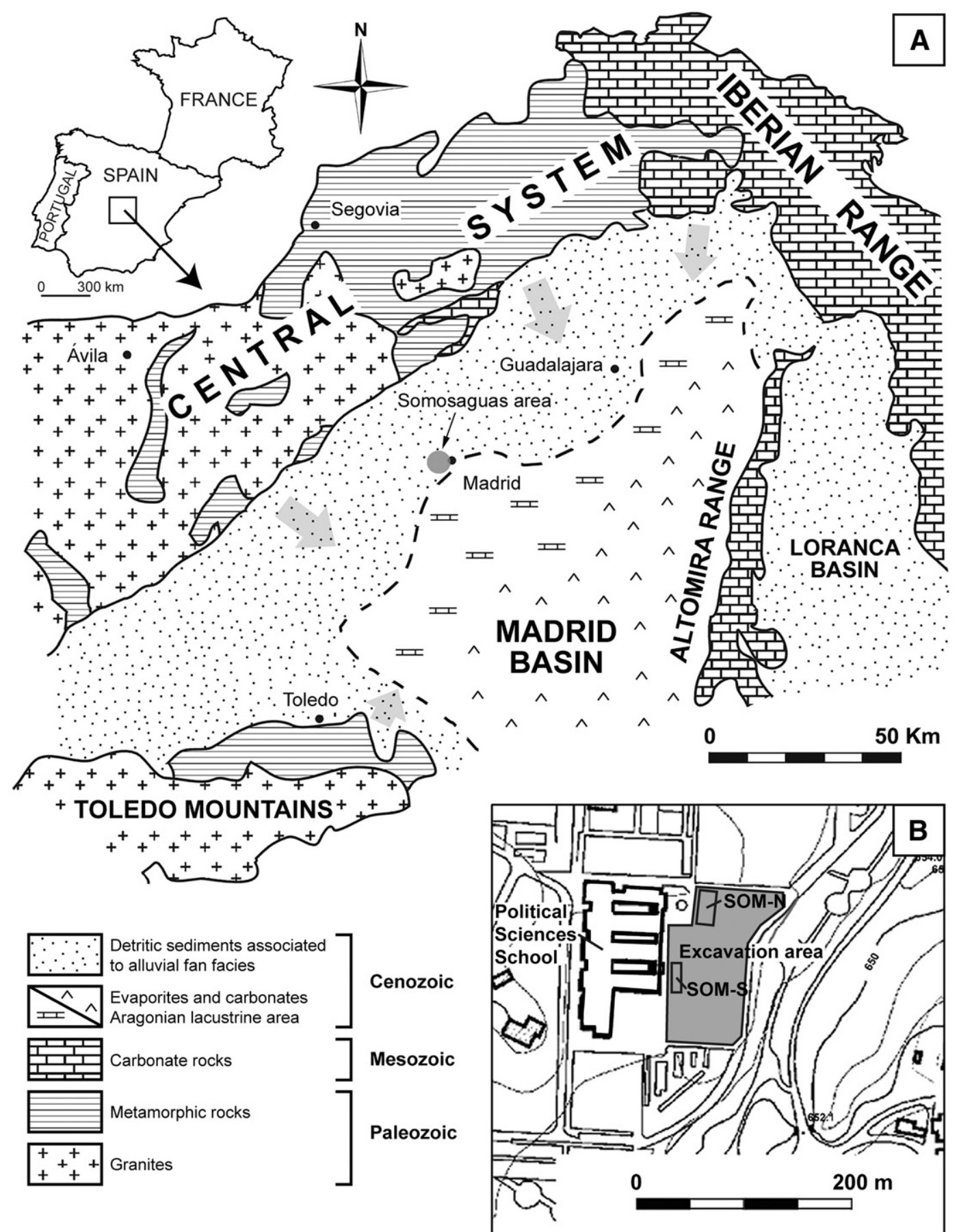

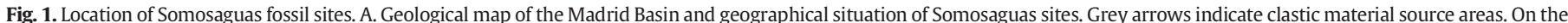

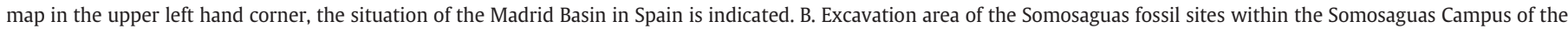
Complutense University of Madrid. SOM-N = Somosaguas-North, SOM-S = Somosaguas-South.

(Modified from Calvo et al. (1989) and Fesharaki et al. (2007).)

(Morales, 2000; Trabada Guijarro et al., 2006). In this article, we present a detailed taphonomic study of the large-mammal assemblage of Somosaguas-North (SOM-N), a fossil locality in the Madrid Basin that lies outside the limits of the city of Madrid. SOM-N was not found in the context of public works and therefore has not been subjected to urgent excavation. This site is part of the Somosaguas paleontological complex, located on the campus of the Complutense University of Madrid in the town of Pozuelo de Alarcón $(\sim 15 \mathrm{~km}$ to the west of the city of Madrid). The site is excavated annually since 1998 by undergraduate and graduate students as part of a paleontological training program under the guidance of instructors and researchers from the aforementioned university (López-Martínez et al., 2000; Castilla et al., 2006; Benítez-López et al., 2009; Fesharaki et al., 2012).

The Somosaguas sites have been studied from a variety of viewpoints which include the stratigraphy, sedimentology and mineralogy of the debris-flow and mud-flow deposits that host the sites (Mínguez Gandú, 2000; Cuevas-González, 2005; Fesharaki et al., 2007, 2015; Carrasco et al., 2008; Díez-Canseco et al., 2012), as well as the systematics (Luis and Hernando, 2000; Mazo, 2000; Salesa and Morales, 2000; Salesa and Sánchez, 2000; Sánchez, 2000; van der Made and Salesa, 2004; Hernández Fernández et al., 2006; Ansón, 2013; Pérez-García, 2013; Pickford and Laurent, 2014) and the biochronology, paleoecology 
and paleobiogeography of the vertebrate fauna (Cuezva and Elez, 2000; López-Martínez et al., 2000; Hernández Fernández et al., 2003, 2006; Cuevas-González, 2005; Pina et al., 2008; Domingo L. et al., 2009, 2012a, 2012b; Perales et al., 2009; Torroba et al., 2010; Hernández-Ballarín et al., 2011; García Yelo et al., 2014; Menéndez et al., 2015; Blanco and Hernández Fernández, 2016). A total of 24 mammal species has been described at the Somosaguas sites. Less abundant remains of birds, lizards and turtles have also been found (Hernández Fernández et al., 2006). Small mammal taxa (mainly rodents) enabled the sites to be dated as belonging to the local zone $\mathrm{E}$ (Luis and Hernando, 2000; Hernández Fernández et al., 2006; Hernández-Ballarín et al., 2011), which is included in the MN5 unit and spans the time between 14.05 and 13.75 Ma (Mein, 1975; Daams et al., 1999).

From a paleoclimatic viewpoint, the Somosaguas sites are contemporaneous with the cooling episode that took place immediately after the Middle Miocene Climatic Optimum as a consequence of the reestablishment of the ice cap in Eastern Antarctica (Flower and Kennett, 1994; Zachos et al., 2001; Lewis et al., 2008). A temperature decrease and increased aridity associated with this event have been directly detected at the Somosaguas sites by means of carbon and oxygen stable isotope analyses in mammalian tooth enamel (Domingo L. et al., 2009, 2012a) and through study of the composition of clastic sediments (Fesharaki et al., 2015). Previous studies based on the small-mammal association, herbivore assemblage, sedimentological characteristics, and the composition of the clay minerals have supported the existence of a savanna biome in the Somosaguas area, in a tropical semiarid climate with an alternation of long dry periods and short wet periods (Luis and Hernando, 2000; Hernández Fernández et al., 2003, 2006; Cuevas-González, 2005; Carrasco et al., 2008; Perales et al., 2009).

Only a few mammalian-dominated debris-flow hosted sites have been described in the fossil record (see 'Discussion' section), and to the best of our knowledge, only one Miocene debris-flow locality, Paşalar (Turkey), has been reported in the literature (Andrews and Ersoy, 1990; Andrews, 1995). In this work, we conduct a detailed taphonomic study of the debris-flow hosted Miocene site of SOM-N in order to improve our knowledge of the biostratinomic and fossildiagenetic processes the mammalian remains underwent in this depositional context. We compare our results with those obtained by Polonio and López-Martínez (2000), who performed a preliminary taphonomic analysis of the fossil material recovered at SOM-N in the first field season. After eighteen field seasons, it has become necessary to reevaluate the taphonomic circumstances that led to the formation of this assemblage. The description by Polonio and López-Martínez (2000) of the taphonomic alterations displayed by the SOM-N fossils was highly qualitative due to the shortage of information available from the first field season. The richness of the taphonomic data gathered throughout the eighteen field seasons has enabled us to provide quantitative data for characterizing the biostratinomic and fossildiagenetic features of the SOM-N assemblage.

Additionally, we have compiled information on all the vertebrate debris-flow assemblages found in the literature that provided detailed taphonomic data. Our aim is to compare the SOM-N data with these sites in order to shed more light on the similarities and differences of the taphonomic signatures displayed by bones subject to this depositional regime.

\section{Geologic context}

\subsection{Madrid Basin}

The Madrid Basin is located in central Spain (Fig. 1) and, together with the Intermediate Depression (also known as Loranca Basin), forms the Tagus Basin. The two sub-basins became independent in the Paleogene with the uplift of the Altomira Range (Alonso-Zarza et al., 2004). The Madrid Basin occupies over $10,000 \mathrm{~km}^{2}$ and is filled by Cenozoic continental deposits that reach a maximum thickness of $3500 \mathrm{~m}$. The mineralogy of these deposits reflects the composition of the mountain ranges surrounding the basin, because they constitute their source areas. To the north and west, the Central System is mainly composed of

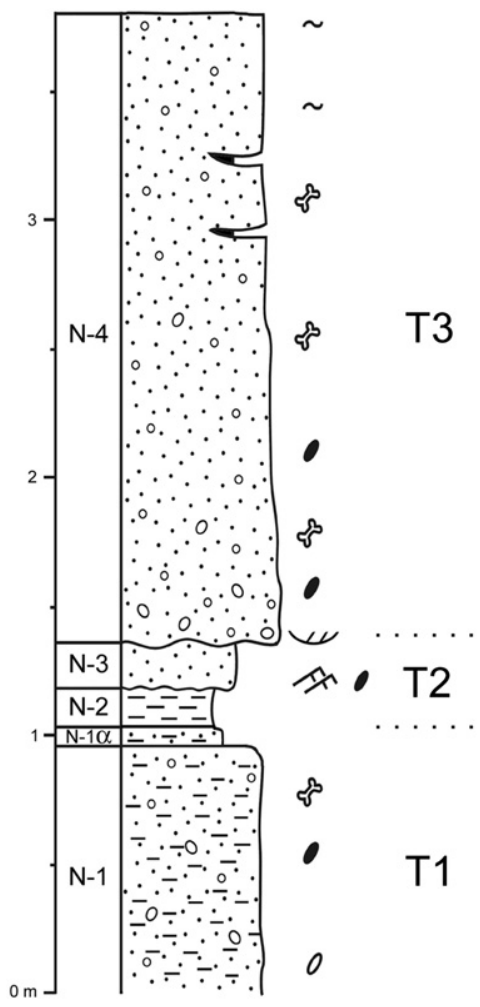

$\therefore \therefore$ Coarse sandstones with gravels

$\therefore \therefore$ Micaceous sandstones

$\because \div-0$ Clayey sandstones

$\because \dot{-}$ Yellowish sandy mudstones

E---- Brownish mudstones

Trough-cross bedding

※ Climbing ripples

$\sim$ Laminar calcrete

- Mud clasts

○ Carbonate chips

\& Fossil bones

Fig. 2. Stratigraphic section of Somosaguas-North (SOM-N) showing the three units $(\mathrm{T} 1, \mathrm{~T} 2, \mathrm{~T} 3)$ described in the text (Modified from Mínguez Gandú (2000) and Fesharaki et al. (2007).) 
granitic and metamorphic rocks; to the south, the Toledo Mountains are also integrated by granitic and metamorphic rocks; to the east, the Iberian and Altomira Ranges are primarily made up of sedimentary rocks (Alonso-Zarza et al., 2004) (Fig. 1).

Neogene sediments are ubiquitous in the Madrid Basin. During the early and middle Miocene, the central area of the basin was occupied by lacustrine and palustrine systems fringed by alluvial fans and fluvial distributary facies which together formed a centripetal drainage system, a sedimentary pattern typical of an endorheic geomorphological setting (Alonso-Zarza et al., 2004). During the late Miocene to the early Pliocene, the Madrid Basin became an exhorheic basin. The Madrid Basin Neogene succession therefore mainly comprises Miocene deposits, overlain by a thin and discontinuous Pliocene sequence (Alonso-Zarza et al., 2004). The Miocene sequence is divided into three units: 1) the Lower Unit (Ramblian to Lower Aragonian, 25-19 Ma), which is composed of different types of sediments responding to the abovementioned concentric model. The central areas present lacustrine deposits mainly comprising evaporites (sulfates, carbonates and chlorides) and, towards the borders of the basin, there are gradations of detritic materials (fluvial systems and alluvial fans), 2) the Intermediate Unit (Middle Aragonian to Lower Vallesian, 19-10 Ma), where the concentric model of the Lower Unit is repeated but the detritic deposits are more extended as a consequence of the re-activation of the Central System uplift, and 3) the Upper Unit (Upper Vallesian to Turolian, 10$5 \mathrm{Ma}$ ), characterized by a change in the sedimentation pattern, as the basin no longer responds to a concentric configuration (Alonso-Zarza et al., 2004). The base of the Upper Unit is made up of terrigenous deposits accumulated by fluvial systems exhibiting a north-south direction. The upper part of this unit is made up of carbonate sediments that accumulated in a fresh-water fluviolacustrine system (AlonsoZarza et al., 2004).

\subsection{Somosaguas fossiliferous area}

The Somosaguas fossil sites are found in deposits belonging to the Intermediate Unit of the Miocene sequence of the Madrid Basin. These deposits correspond to the proximal facies of the aforementioned concentric paleogeographic setting and mainly consist of matrix-supported arkosic facies that are interpreted as middle to distal alluvial fan deposits, whose source area was the Central System Range, located $30 \mathrm{~km}$ to the northeast of the sites (Hoyos et al., 1985; Fesharaki et al., 2015) (Fig. 1).

The Somosaguas fossiliferous area has two main excavation sites, Somosaguas-North (SOM-N), where the excavation of large-mammal remains takes place, and Somosaguas-South (SOM-S), where sediment is extracted and processed in order to obtain small-mammal remains (Fig. 1). Additionally, there are nine prospection trenches in the nearby

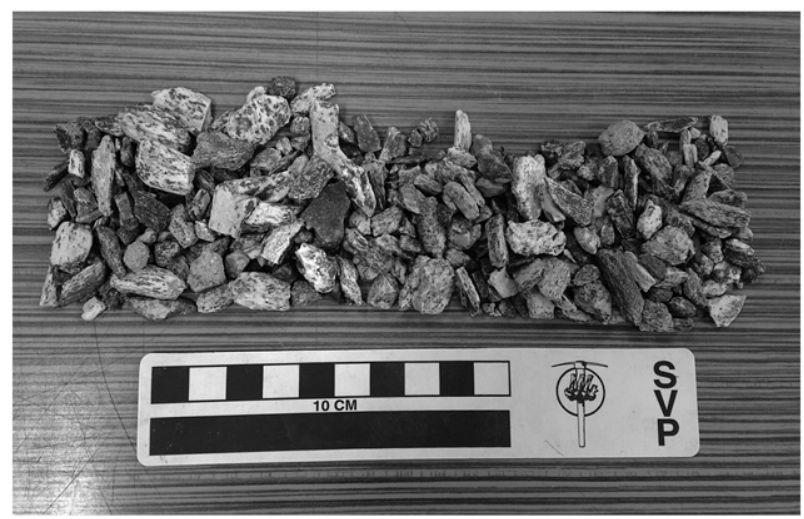

Fig. 3. Content of one of the splinter bags from SOM-N. Splinters are fragmented fossil bones smaller than $3 \mathrm{~cm}$ with undetermined anatomic and taxonomic adscription. The total number of bags containing splinters at SOM-N is 814
Table 1

Large mammal taxa recovered at SOM-N expressed as Number of Identified Specimens (NISP) and percentages. Indet. = indetermined.

\begin{tabular}{llll}
\hline & Family/Order & NISP & \% \\
\hline Amphicyon sp. & Amphicyonidae/Carnivora & 10 & 0.15 \\
Hemicyon sp. & Hemicyonidae/Carnivora & 1 & 0.02 \\
Pseudaelurus sp. & Felidae/Carnivora & 2 & 0.03 \\
Carnivora indet. & Carnivora & 53 & 0.80 \\
Anchitherium cursor & Equidae/Perissodactyla & 484 & 7.34 \\
Prosantorhinus douvillei & Rhinocerotidae/Perissodactyla & 92 & 1.40 \\
Retroporcus complutensis & Suidae/Artiodactyla & 79 & 1.20 \\
Micromeryx sp. & Moschidae/Artiodactyla & 34 & 0.52 \\
Heteroprox sp. & Cervidae/Artiodactyla & 6 & 0.09 \\
Tethytragus sp. & Bovidae/Artiodactyla & 39 & 0.59 \\
Ruminantia indet. & Artiodactyla & 639 & 9.69 \\
Artiodactyla indet. & Artiodactyla & 10 & 0.15 \\
Gomphotherium angustidens & Gomphotheriidae/Proboscidea & 786 & 11.92 \\
Indetermined & & 4357 & 66.10 \\
& Total Carnivora & 66 & 1.00 \\
& Total Perissodactyla & 576 & 8.74 \\
& Total Artiodactyla & 807 & 12.24 \\
& Total Proboscidea & 786 & 11.92 \\
& Total Indetermined & 4357 & 66.10 \\
\hline
\end{tabular}

area, two of which (Cata-2 and Cata-4) are currently being excavated (Díez-Canseco et al., 2012; Fesharaki, 2016).

The stratigraphic sequence of the Somosaguas paleontological area is made up of two fossiliferous units, T1 and T3, with a non-fossiliferous unit located between them, T2 (Mínguez Gandú, 2000) (Fig. 2). Underlying these three units, six more units have been recently described, which are called from base to top T-5, T-4, T-3, T-2, T-1 and T0 (Díez-Canseco et al., 2012; Fesharaki, 2016). Their description was based on borehole continuous cores and their fossil content has not yet been evaluated. Consequently, only T1 to T3 units will be described here in detail (Fig. 2).

$\mathrm{T} 1$ unit consists of clayey arkoses, with the clay content increasing towards the top unit, and has been interpreted as the result of mudflow deposits. The visible thickness of this unit is $57 \mathrm{~cm}$. The SOM-S fossil site crops out in this type of deposits, which are rich in small-mammal remains (Luis and Hernando, 2000; Mínguez Gandú, 2000).

T2 unit comprises rippled micaceous sandstones interbedded with thin mudstone layers and lacks fossil remains (Mínguez Gandú, 2000).

Table 2

Skeletal element frequencies at SOM-N expressed as Number of Identified Specimens (NISP) and percentages. Indet. = indetermined.

\begin{tabular}{lll}
\hline Element & NISP & $\%$ \\
\hline Antler & 2 & 0.03 \\
Skull & 72 & 1.09 \\
Mandible & 62 & 0.94 \\
Tooth & 603 & 9.15 \\
Tooth indet. & 1320 & 20.02 \\
Vertebra & 154 & 2.34 \\
Rib & 191 & 2.90 \\
Clavicle & 1 & 0.02 \\
Scapula & 21 & 0.32 \\
Pelvis & 26 & 0.39 \\
Humerus & 14 & 0.21 \\
Radius & 18 & 0.27 \\
Ulna & 8 & 0.12 \\
Femur & 17 & 0.26 \\
Tibia & 34 & 0.52 \\
Patella & 23 & 0.35 \\
Carpal & 171 & 2.59 \\
Tarsal & 144 & 2.18 \\
Metapodial & 149 & 2.26 \\
Phalanx & 185 & 2.81 \\
Sesamoid & 132 & 2.00 \\
Indetermined & 3245 & 49.23 \\
Total & 6592 & \\
\hline
\end{tabular}




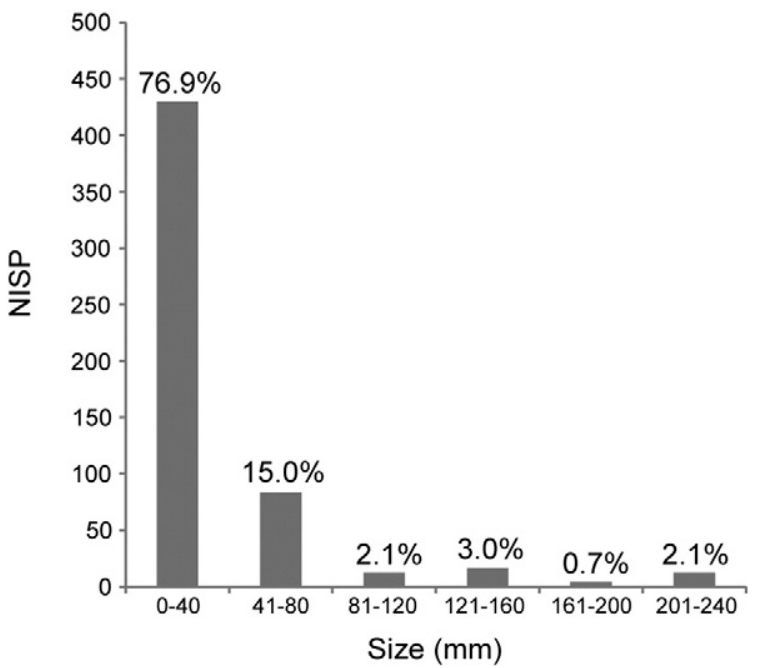

Fig. 4. Bone maximum dimension size frequency at SOM-N. NISP $=$ Number of Identified Specimens. This analysis is performed on the taphonomically analyzed subsample (see 'Materials' section), and splinters $<3 \mathrm{~cm}$ from this subsample are therefore included.

From a maximum thickness of $200 \mathrm{~cm}$ at SOM-S, this unit decreases in thickness towards the north. These deposits are interpreted as streammouth lobes or terminal splays of streams when they reach their base level in a pond (Díez-Canseco et al., 2012).

T3 unit consists of poorly-sorted coarse arkosic sandstones and fine conglomerates with a silty-clay matrix, interbedded with irregular clay levels. There are pebbles up to $10 \mathrm{~cm}$ in size, although mean size corresponds to that of coarse sands. This unit, interpreted as the result of successive debris-flow deposits (Mínguez-Gandú, 2000; Díez-Canseco et al., 2012; Fesharaki, 2016), reaches a thickness of over $300 \mathrm{~cm}$ and contains abundant remains of vertebrates, including mammals as the predominant group, but remains of lizards, turtles and birds are also present. Its large-mammal fossil content constitutes the subject of the present study (SOM-N). T3 unit is also being excavated in the prospection trenches known as Cata-2 and Cata-4.

Cuevas-González (2005) suggested that large arkosic mass-flow alluvial fans from the Madrid Basin formed under an arid climatic regime presenting intense seasonal rain, since mass transport deposits predominate over fluvial facies, which are practically non-existent.

Although bedding planes are not easily recognizable in T3 unit, Elez (2005) performed a three-dimensional reconstruction of the distribution of 1300 remains from this unit and suggested the existence of up to 3 levels where fossils were more concentrated and separated by levels exhibiting an apparent scarcity of fossils. This configuration would be typical of multiple, episodic debris flows (Elez, 2005; Hernández Fernández et al., 2006). Fesharaki et al. (2015) analyzed from a petrographic viewpoint six successive samples from T3 unit and concluded that the differences in the composition of the clastic materials could point to a multi-episodic process, with sediments deposited by different pulses associated with a sequence of continuous cooling (see also Domingo et al., 2009). Well-defined limits to these episodes cannot be established, given the massive character of the deposits (T3 unit), which are devoid of clear bounding surfaces and major sedimentary structures. The entire stratigraphic sequence displays a dip of $2^{\circ}$ to $3^{\circ}$ towards the south. This dipping responds to the depositional slope and not to tectonic deformation (Hernández Fernández et al., 2006).

\section{Taphonomic background}

Polonio and López-Martínez (2000) conducted a preliminary taphonomic study based on material recovered at SOM-N during the first field season $(n=211)$. Highly fragmented, unidentifiable bones (i.e. splinters) were extremely abundant, so the material recovered and observed by these authors mainly belonged to bones larger than $3 \mathrm{~cm}$ or smaller than $3 \mathrm{~cm}$ but identifiable.

The abovementioned authors observed that the assemblage consisted of remains showing diverse preservational states that included relatively well preserved remains, remains rounded due to abrasion, and highly fragmented remains that were taxonomically and anatomically unidentifiable. There was no contact among the bones in the site. Rather, they were 'floating' in the sedimentary matrix in the same fashion as rock pebbles. Remains were disarticulated and disassociated. The bones showed a trend alignment along the north-south axis. When plunge data were considered, bones were observed to present a mean dip of $15^{\circ}$ and a preferential direction of dip towards the south (Polonio and López-Martínez, 2000).

Appendicular skeleton bone fragments, rib fragments and isolated teeth were the most abundant remains in the assemblage. A total of $54 \%$ of the remains were taxonomically undetermined. Among the determined specimens, Ruminantia (14\%), Proboscidea (12\%) and Equidae (12\%) were the best represented taxa (Polonio and López-Martínez, 2000). Although there were no quantitative data on the age representation of large mammals at SOM-N, there appeared to be an important presence of juvenile individuals, as evidenced by the presence of long bones with unfused epiphyses, mandibles with decidual dentition as well as infantile and juvenile bone microstructures detected in paleohistological sections (Cuezva and Elez, 2000; Polonio and López-Martínez, 2000; Hernández Fernández et al., 2006).

Regarding the preservation of the bones, fragmentation was the most significant taphonomical alteration detected by Polonio and López-Martínez (2000). Bones showed low integrity, a fact that made bone splinters of different sizes and shapes the most abundant type of remain in the assemblage. Remains did not display features indicative of advanced weathering stages. Given the polishing and rounding of some splinters, the authors indicated that these elements could have undergone intense weathering prior to fragmentation. Bones showed
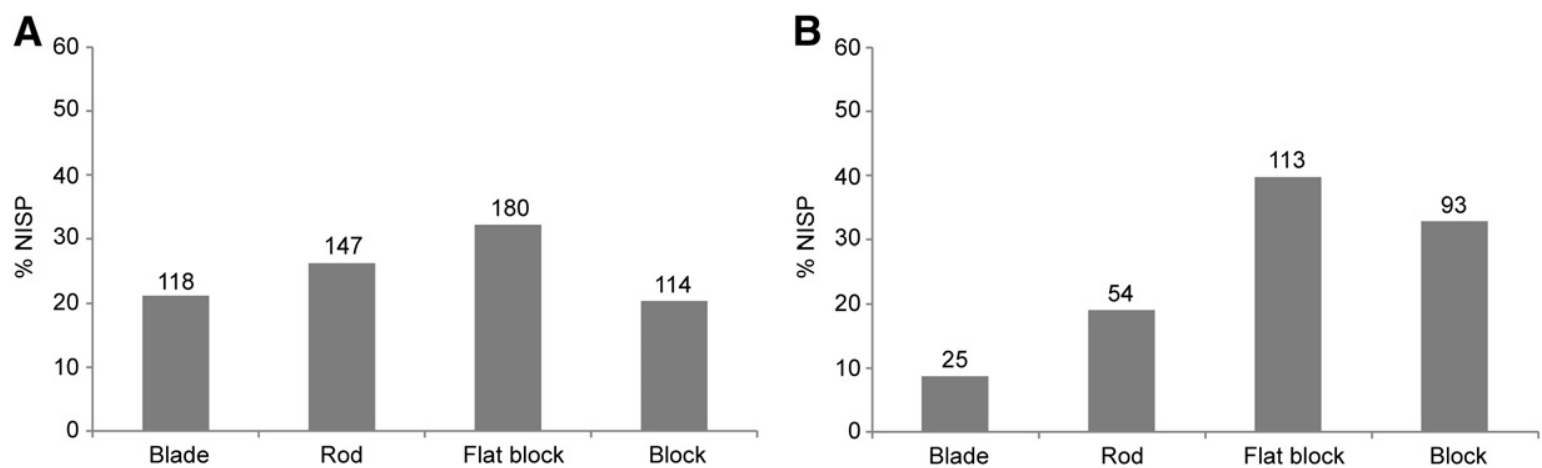

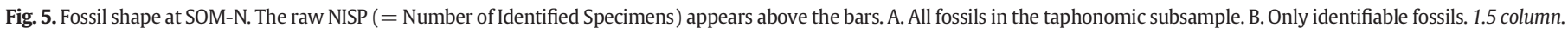


A $\longleftarrow$ N $\quad$ coordinates $(\mathrm{cm})$

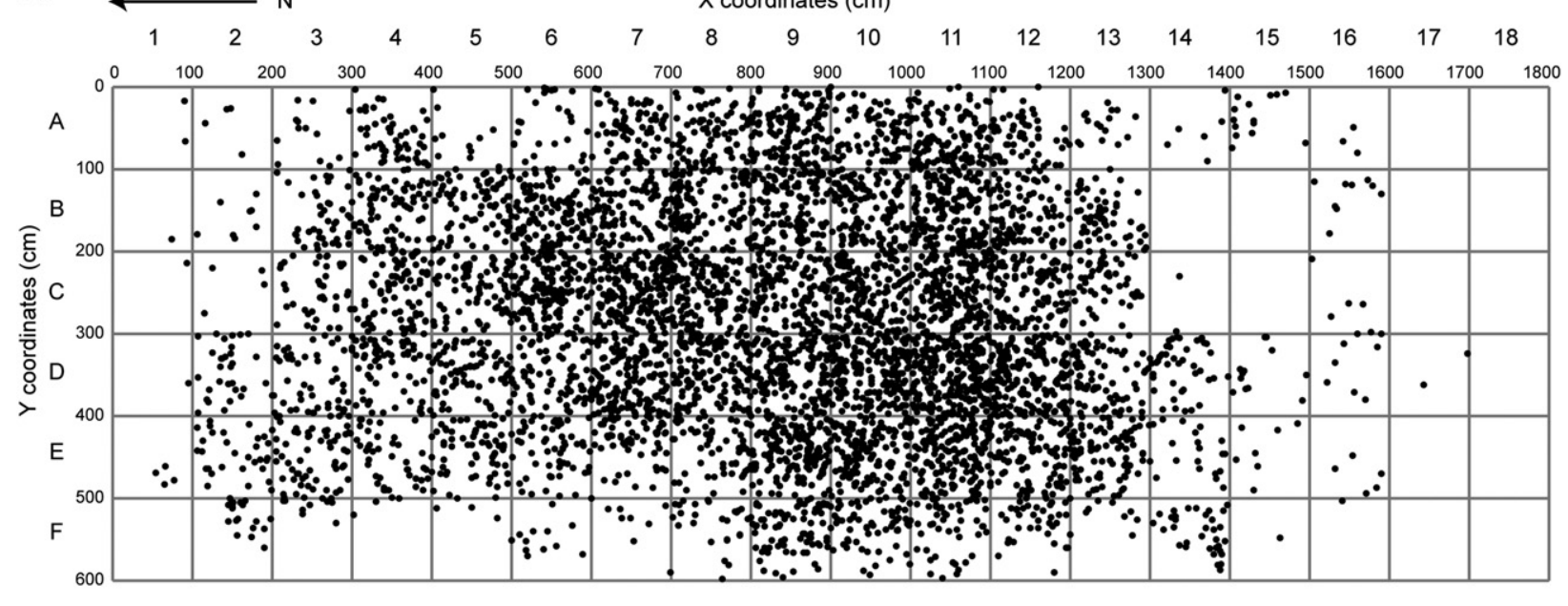

B

$X$ coordinates $(\mathrm{cm})$

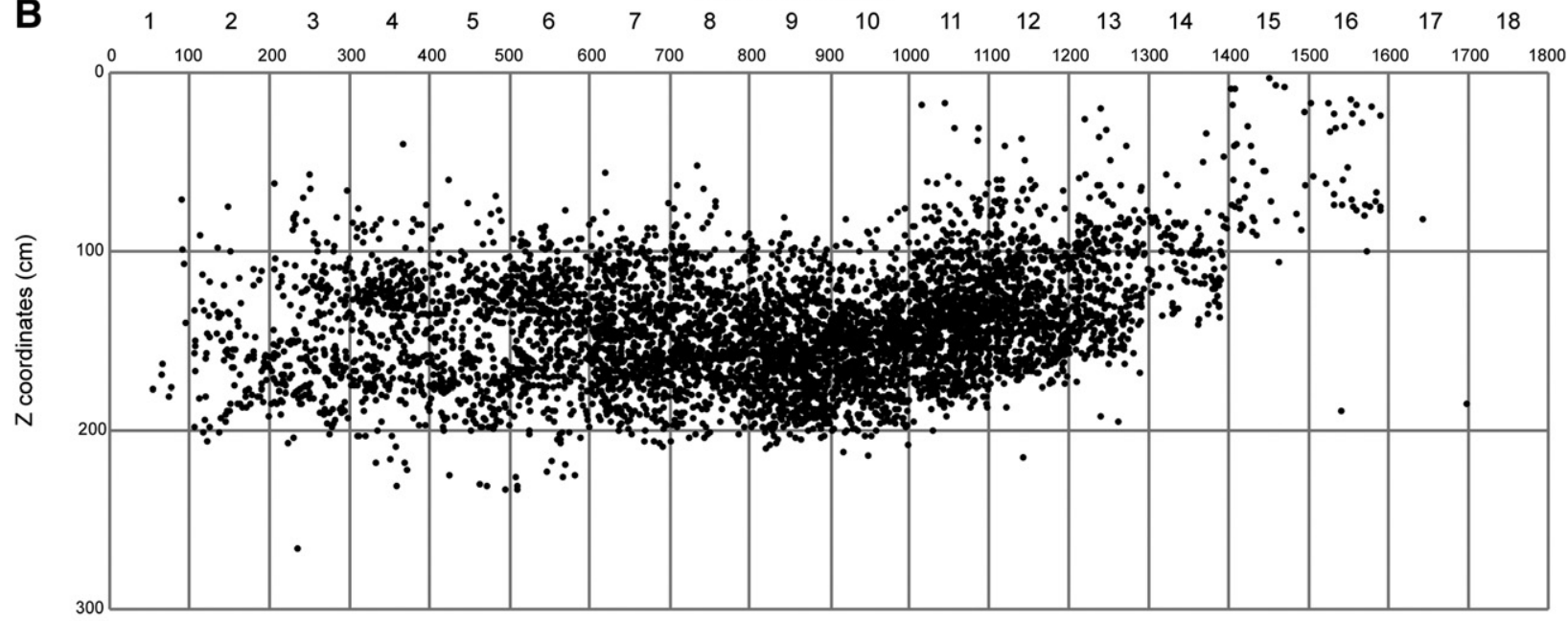

C

A $\quad$ B

$Y$ coordinates $(\mathrm{cm})$

$\mathrm{C}$

D

E

$\mathrm{F}$

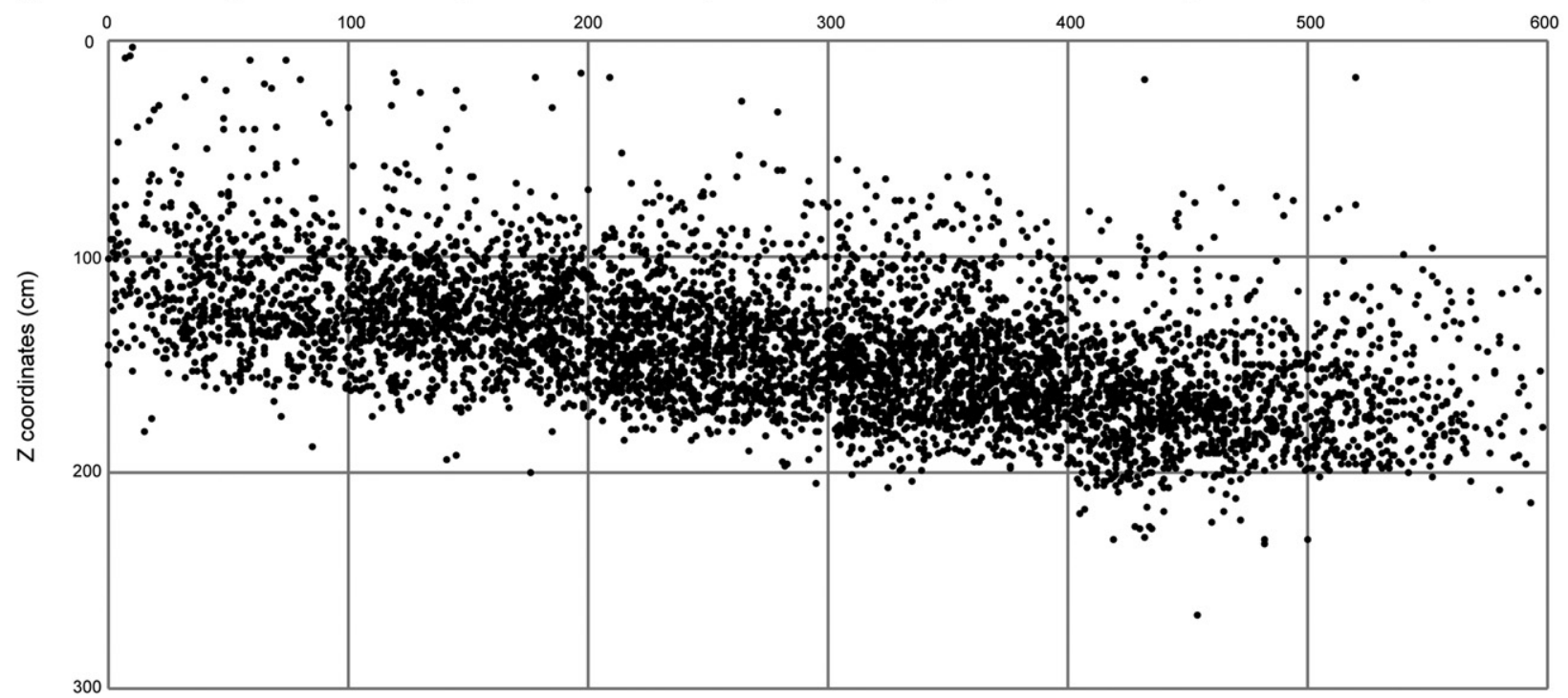

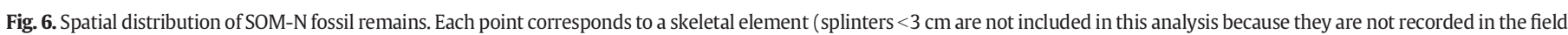

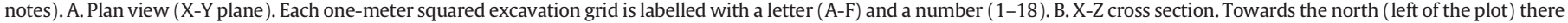
may be two fossil-rich levels separated by a level poorer in remains (vertical scale is exaggerated) C. Y-Z cross section. 
no signs of corrosion, digestion, or carnivore and rodent activity. Some elements displayed a powdered texture.

These authors concluded that the SOM-N assemblage comprises remains showing a range of preservational states, from well preserved and almost complete to highly fragmented specimens (although the latter ones predominate). Based on these features and the sedimentology of the site, Polonio and López-Martínez (2000) suggested that mass transport during debris-flow episodes was the agent responsible for the accumulation of the fossiliferous assemblage.

\section{Materials}

A total of 6592 large-mammal remains has been recovered at SOM-N between 1998 and 2014 (when we were preparing this study, the excavation of 2015 had not taken place). The Somosaguas remains are currently housed in the collections of the Paleontology Department at the Complutense University of Madrid. The remains from field seasons 1998 to 2012 are fully prepared.

As previously mentioned, splinters (i.e. fragmented fossil bones smaller than $3 \mathrm{~cm}$ with an undetermined anatomic and taxonomic adscription) are very common at SOM-N (Fig. 3). They are recovered but, due to their great abundance they are not recorded in the field notes and, as a result, in the total account of elements. This could introduce a bias against small, unidentifiable elements, but it is impractical to record all the data on splinters during the field seasons. In any event, direct observation of bone material carried out in this study included splinters, so that we could obtain sound knowledge of the taphonomic alterations present in this type of remains.

The enormous amount of remains collected since the first excavation in 1998 made it unfeasible to make direct taphonomic observations on all of the elements. We therefore performed the direct observation of taphonomic modifications in a subsample of 559 fossil remains (10\% of the total material recovered between 1998 and 2012). We randomly selected the subsample but considering material coming from all the field seasons in order to avoid biases derived from the observation of fossils from only some of the field seasons. As previously indicated, we also included splinters in this taphonomic subsample.

Several taphonomic variables can be studied with the use of the information directly available from the field notes (i.e., direct observation of fossil bones is not necessary), such as the anatomical and taxonomical composition of the assemblage or the spatial distribution and orientation of fossils in the site. Thus, we employed the information from all the material to evaluate these taphonomic variables.

\section{Methods}

SOM-N is excavated following standard techniques commonly used in fossil vertebrate excavations (Eberth et al., 2007a). Information recorded in the field corresponds to the taxonomical and anatomical identification of the remains, the $\mathrm{X}, \mathrm{Y}$ and $\mathrm{Z}$ coordinates, trend and plunge of fossils with a dominant longer axis, and degree of articulation.

The SOM-N site has an area of over $100 \mathrm{~m}^{2}$. The excavation area is divided into $1 \mathrm{~m}^{2}$ grids. The spatial distribution coordinates (X, Y and $Z$ ) are obtained for each fossil from a datum that remains constant year after year. $X$ and $Y$ are surface coordinates, whereas $Z$ represents the depth at which the remains are recovered. These coordinates are measured from the center of each bone. As previously indicated, anatomically identifiable bones of any size, as well as unidentifiable bones larger than $3 \mathrm{~cm}$, were mapped and recorded in the field notes.

Provided that there are no associated or articulated remains at SOM-N, the index we selected to account for taxonomical and anatomical compositions is the Number of Identifiable Specimens (NISP) (Badgley, 1986). In assemblages where formerly articulated remains have been widely dispersed and have accumulated as isolated remains, as it is the case at SOM-N, NISP is the appropriate method to account for taxonomical abundance (Badgley, 1986). Moreover, the limits of the deposit containing SOM-N fossil remains have not yet been established, making NISP the most suitable index for estimating the abundance of the taxa at this site.

Although Polonio and López-Martínez (2000) used Voorhies Groups to analyze the potential of remains to be transported (Voorhies, 1969), we excluded this analysis from our study due to the low integrity of the remains at SOM-N. Voorhies Groups were established according to intact skeletal morphologies (Voorhies, 1969). Additionally, the hydraulics of debris flows differ substantially from those encountered in the experimental flume studies of Voorhies (Voorhies, 1969; Britt et al., 2009).

Rose diagrams were drawn for bones larger than $10 \mathrm{~cm}$ to assess the possible existence of preferential orientations. The significance of the bone orientations was evaluated with Rayleigh's tests.

We performed an assessment of sorting by specimen shape by measuring the three major linear dimensions of remains (D1 > D2 > D3), perpendicular to one another as suggested by Zingg (1935). Ratios D2/D1 and D3/D2 are used to classify particles into four morphological categories: blade, rod, flat block and block. Alcalá (1994) indicated that a higher variety and diversity of shapes would be indicative of a limited influence of transport processes, whereas the opposite would imply pre-burial selection of the remains. Nevertheless, Britt et al. (2009) warned about the poor sorting capacity of debris-flow deposits, so all types of shapes can be expected to be present at this type of sites.

Bone modification data (weathering, abrasion, trampling, carnivoran and rodent activity, root action and fragmentation) were obtained following examination of the taphonomic subsample under a binocular microscope. Weathering provides an indication of bone deterioration due to physical and chemical agents and is indicative of the time elapsed between the death of the animal and final burial (Behrensmeyer, 1978). Behrensmeyer (1978) constructed a weathering scale based on the study of modern bones at Amboseli National Park (Kenya), which is characterized by a tropical, semiarid climate. Bones have been demonstrated to weather much faster in this type of climatic zones than in temperate or arctic zones (e.g., Andrews and Armour-Chelu, 1998; Miller et al., 2013). As previously indicated, a savanna biome in a tropical semiarid climate has been inferred for the Somosaguas area during the Middle Miocene, very different from the Mediterranean continental climate currently existing in this area. We therefore consider that the weathering scale estimated at Amboseli National Park can be applied in our study. Weathering was measured on a scale from 0 (not weathered) to 5 (extremely weathered), where each category relates to a number of years since death: Stage 0 ( $0-1 \mathrm{yr})$, Stage 1 ( $0-3 \mathrm{yr})$, Stage 2 (2-6 yr), Stage 3 (4-15 yr), Stage 4 and Stage 5 (6-15 yr) (Behrensmeyer, 1978). Abrasion refers to the erosion caused to the bones by means of friction with sedimentary particles. To analyze abrasion, we used the three stages proposed by Alcalá (1994): intact bone (Stage 1 ), rounded bone (Stage 2 ) and polished and smoothed bone (Stage 3). Abrasion stage is a proxy of the intensity and/or time of interaction of sediment particles with bones and does not necessarily indicate distance of transport (Behrensmeyer, 1991; p. 309).

As for the breakage analysis, perpendicular and smooth fractures usually occur in recrystallized or permineralized bone and are produced by diagenetic processes, such as sediment pressure or tectonic movements (Lyman, 1994). In turn, spiral and irregular or sawtoothed fractures occur in relatively fresh, collagen-rich bones and can be generated by different agents, including carnivoran activity and trampling (Lyman, 1994). Apart from fracture angle, we accounted for number of fractures, degree of bone completeness and fracture surface as defined by Pesquero et al. (2013). Weathering, abrasion and breakage analyses were performed on 1) the whole taphonomic subsample analyzed and 2) the subsample excluding unidentifiable bone fragments. 


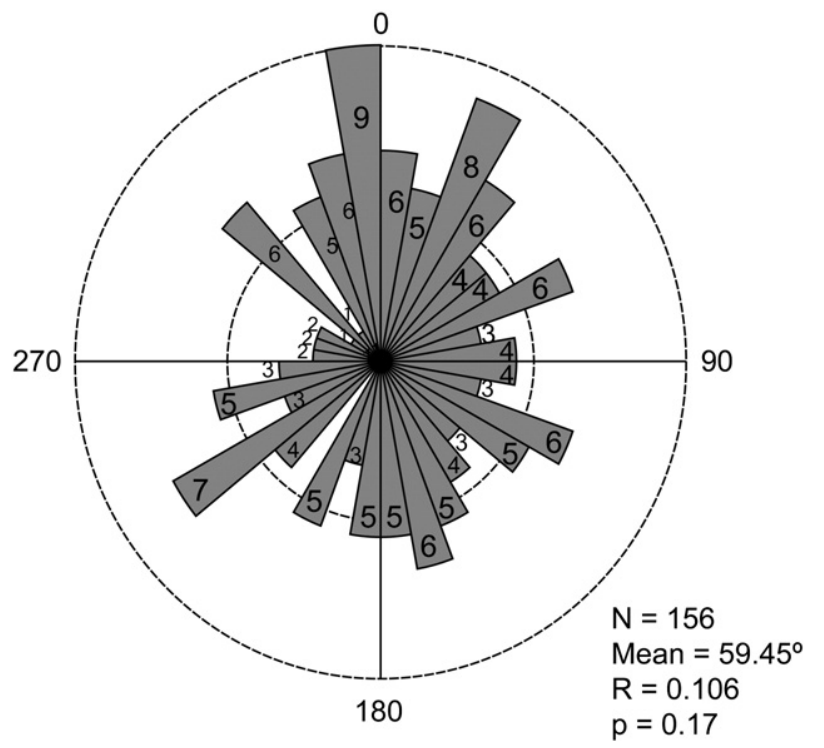

Fig. 7. Long bone $(>10 \mathrm{~cm})$ orientation at SOM-N. Rayleigh's test $(\mathrm{R})$ demonstrates that bones are randomly oriented (i.e., $p=0.17$ ).

\section{Results}

\subsection{Assemblage data}

The number of large-mammal species at SOM-N is 10 (Table 1 ). The NISP is 6592. Taxonomically unidentifiable elements are represented by 4357 specimens and therefore constitute two thirds of the SOM-N largemammal assemblage. Of the taxonomically identifiable elements, the proboscidean Gomphotherium angustidens is the most abundant taxon (NISP $=786)$, followed by Ruminantia indet. (NISP $=639$ ) and by the equid Anchitherium cursor (NISP $=484$ ). Carnivores are the least abundant large-mammal group, represented by only 66 specimens ( $1 \%$ of the total assemblage; $2.95 \%$ of the taxonomically identifiable specimens).

Table 2 shows the skeletal element proportions represented at SOMN. A total of $49.23 \%$ of the remains were anatomically unidentifiable. Unidentifiable teeth (20.02\%), most of these heavily fragmented, along with identifiable teeth (9.15\%), constitute the most abundant skeletal elements of the assemblage. Moderately abundant elements, making up over a $2 \%$ of the assemblage, include vertebrae, ribs, carpal bones, tarsal bones, metapodials, phalanxes and sesamoids (Table 2 ). No associated or articulated skeletal elements have been found, i.e., the entirety of the skeletal remains were disarticulated and isolated. The SOM-N largemammal assemblage is dominated (76.9\%) by remains displaying a maximum dimension $\leq 4 \mathrm{~cm}$ and fossil bones $>8 \mathrm{~cm}$ are very scarce (8.1\%) (Fig. 4, Supplementary Table 1). The fossil shape categories are represented in Fig. 5 (see also Supplementary Table 2). Splinters are

A

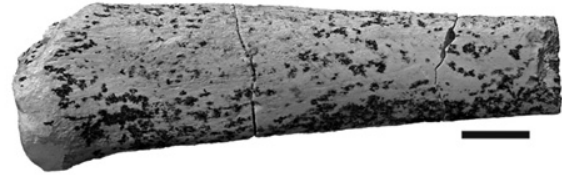

Weathering stage 0

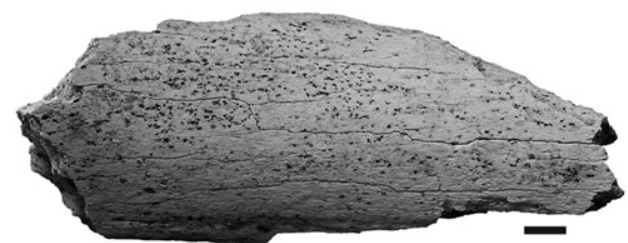

Weathering stage 1

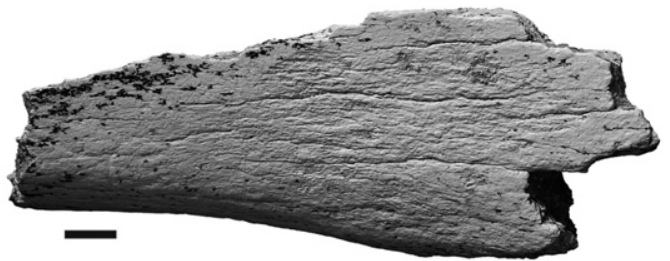

Weathering stage 2

B

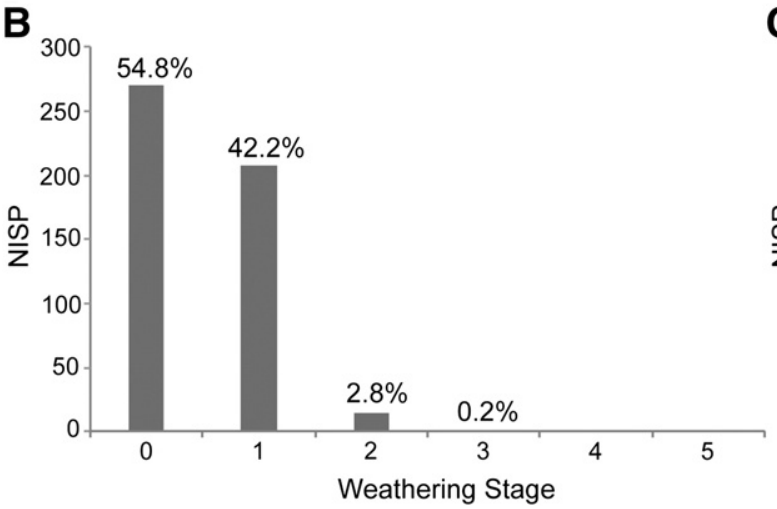

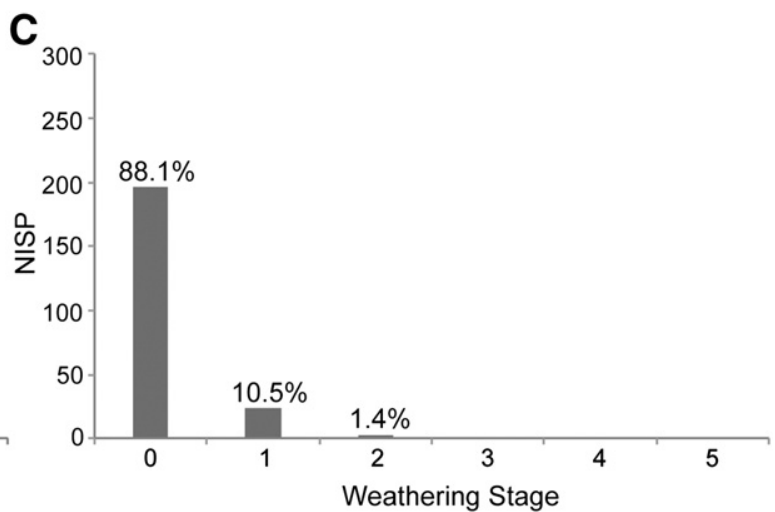

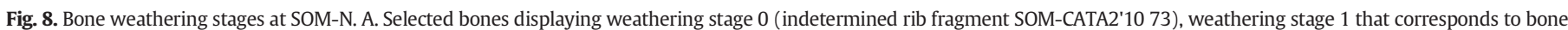

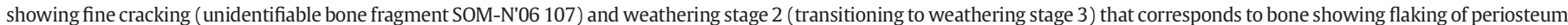

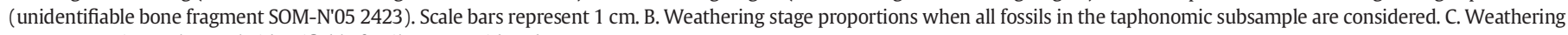
stage proportions when only identifiable fossils are considered. 
mainly classified in the 'Blade' and 'Rod' categories. Ribs, carpals, tarsals and phalanges were mainly classified as 'Flat block' and 'Rod'. Teeth, depending on their degree of breakage, fell under the 'Flat Block', 'Block' and 'Rod' categories. The very few mandibles that could be studied were classified in the 'Blade' category.

\subsection{Spatial data}

SOM-N has an excavated area of $\sim 100 \mathrm{~m}^{2}$, although the site expands laterally, as demonstrated by the continuity of the deposits and fossils in several prospective trenches excavated in the vicinities of SOM-N. The lateral limits of the fossiliferous deposit have not yet been established. Therefore, the spatial distribution of fossil bones in plan view (X-Y coordinates) is only indicative of the extension of the current excavation area (Fig. 6A). Central grids have been excavated for a greater number of years, and the density of bones is therefore higher in this part of the excavation area compared to the outer rim. In the X-Z cross section, there appear to be two distinct fossil-rich levels towards the North of the site, but these levels are indistinguishable towards the southern area (Fig. 6B). In the Y-Z section, fossil remains are sloped (Fig. 6C), but this morphology only reflects the progression of the excavation. No levels are recognizable in the Y-Z section.

We also analyzed the spatial distribution of anatomically identifiable bones (i.e., we removed all the undetermined bones from the analysis, mainly bone and enamel splinters) to test whether these bones accumulated preferentially in certain parts of the excavation area (Supplementary Fig. 1). We did not observe major differences, and the identifiable bones can therefore be deemed to be uniformly distributed across the whole area and depth.

Mean trend and plunge are $59.45^{\circ}$ and $17.64^{\circ}$, respectively. Rayleigh's test indicates that long bones $(>10 \mathrm{~cm}$ ) are randomly oriented (Fig. 7).

\subsection{Bone modification data}

Bones showing no weathering alteration (Stage 0) predominate at SOM-N, but this stage is more abundant on excluding the unidentifiable bone fragments (Fig. 8, Supplementary Table 3). Weathering Stage 1 is present in $42.2 \%$ of the taphonomically analyzed subsample but this percentage decreases to $10.5 \%$ when unidentifiable bone fragments are excluded. Bones displaying weathering Stages 2 or higher are very scarce at SOM-N (Fig. 8).

Bones in the three abrasion stages are present at SOM-N (Fig. 9, Supplementary Table 4). When the complete subsample is considered, abrasion stages 2 and 3 are predominant (48.3\% and 34.0\%, respectively), a fact that indicates that bones show rounding and polishing or smoothening (Fig. 9B). When the unidentifiable bone fragments are excluded from the analysis, abrasion stage 2 is still predominant (52.5\%), but in this case, abrasion stage 1 (36.3\%), which is indicative of bones showing no signs of rounding or polishing, is more abundant than stage 3 (11.3\%) (Fig. 9C).

In general, the SOM-N remains display low integrity; thus, breakage represents the most pervasive taphonomic alteration (Fig. 10, Supplementary Table 5 ). More than $70 \%$ of the bones exhibit three or more fractures, even when unidentifiable bone fragments are excluded from the evaluation (Fig. 10A, E). In terms of the completeness of the original bone morphology, when the whole sample is considered, $74.6 \%$ of the remains are represented by less than half of the original bone morphology (Fig. 10B). When the unidentifiable bone fragments are excluded, this percentage decreases to $47.4 \%$, and the complete and almost complete (missing some bone chips) categories reach $37.5 \%$ (Fig. 10F).

The most abundant fracture angle category is the combination of perpendicular, spiral and longitudinal fractures (Fig. 10C, G). As for the fracture surface, the combination of smooth and irregular (37.7\%) and only irregular (25.8\%) categories are predominant when the whole subsample is considered (Fig. 10D). When unidentifiable bone fragments are excluded, the combination of smooth and irregular fracture surface (45.3\%) constitutes the most common category (Fig. 10H).

Six skeletal elements (1.1\% of the taphonomically analyzed subsample) exhibit root marks. Most of these were produced by modern roots (Fig. 11). Some remains (<1\%) display $\sim 1 \mathrm{~mm}$ wide linear marks of varying millimetric to centimetric length (Fig. 12). Some marks are perpendicular to each other (Fig. 12A, B) and others are parallel (Fig. 12C, D). In pre-human fossil sites, these thin linear marks seem to result mainly from sedimentary particle scratching caused by trampling (Behrensmeyer et al., 1986, 1989). No evidence of rodent or carnivore marks or digestion alteration has been observed at SOM-N.

SOM-N remains exhibit a whitish to beige color, only obscured by patches of manganese oxides (Figs. 8, 9, 12, 13). Manganese oxides are common along fractures, but they are also spread throughout the bone surfaces. These oxides are present in both identifiable and unidentifiable bones. SOM-N remains show no evidence of mineral crusting.
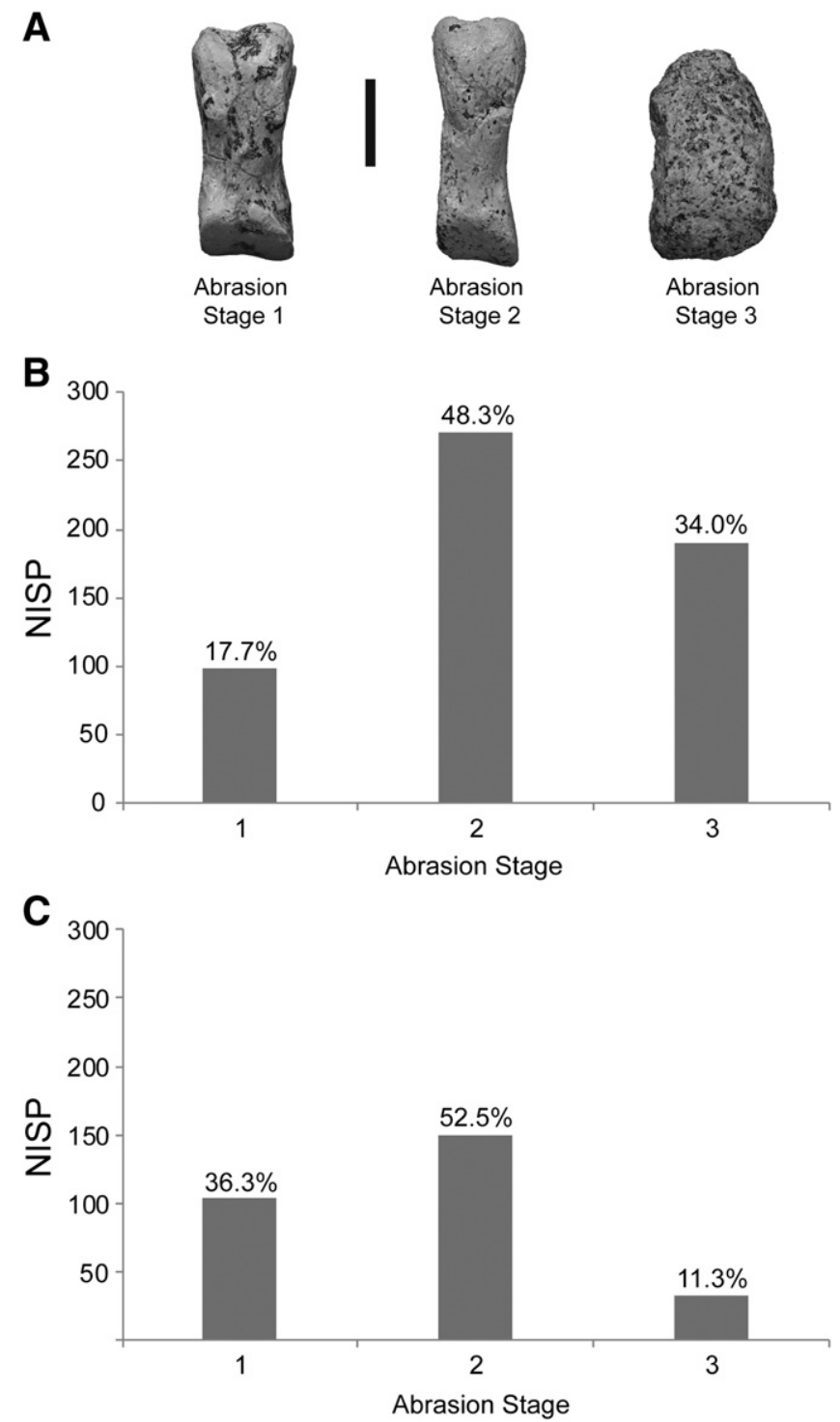

Fig. 9. Bone abrasion stages at SOM-N. A. Selected bones displaying abrasion stage 1 that corresponds to intact bone (Anchitherium lateral first phalanx SOM-CATA2'07 1), abrasion stage 2 that corresponds to rounded bone (Anchitherium lateral first phalanx SOM-CATA2'10 109) and abrasion stage 3 that corresponds to polished and smoothed bone (unidentifiable bone fragment not numbered). Scale bar represents $1 \mathrm{~cm}$. B. Abrasion stage proportions when all fossils in the taphonomic subsample are considered. C. Abrasion stage proportions when only identifiable fossils are considered. 
A

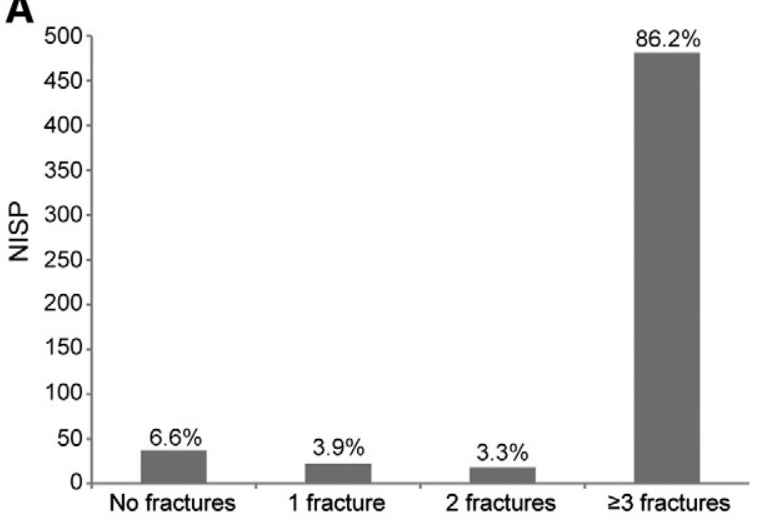

B

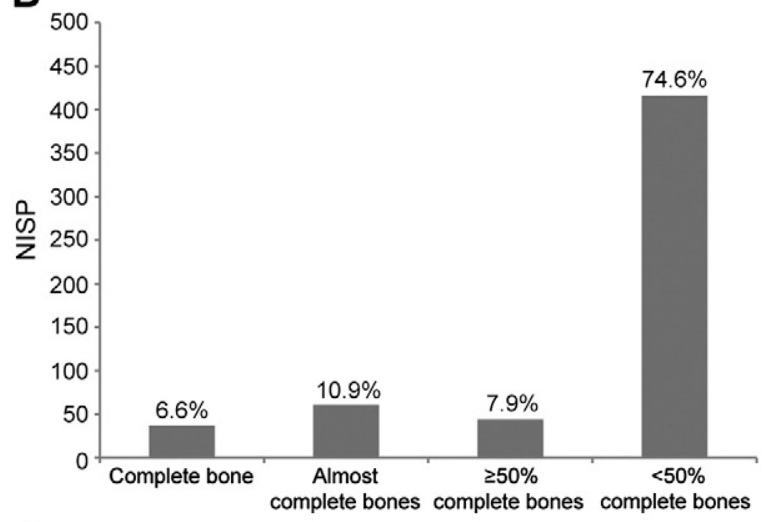

C

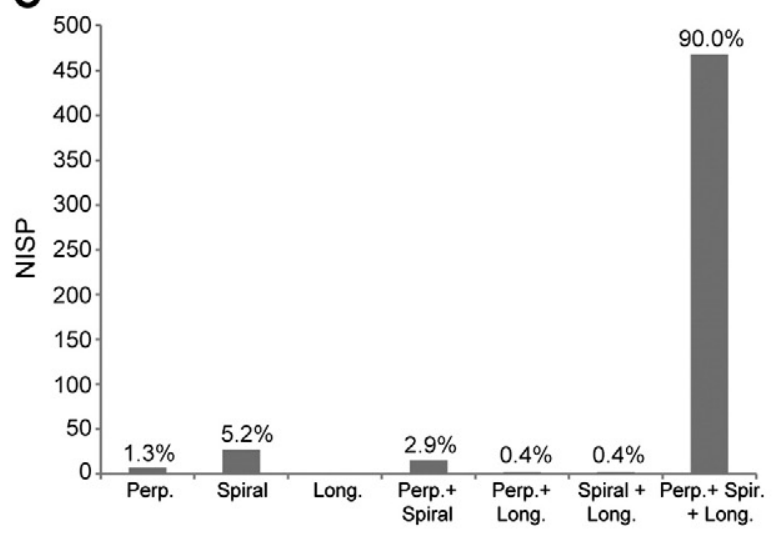

D

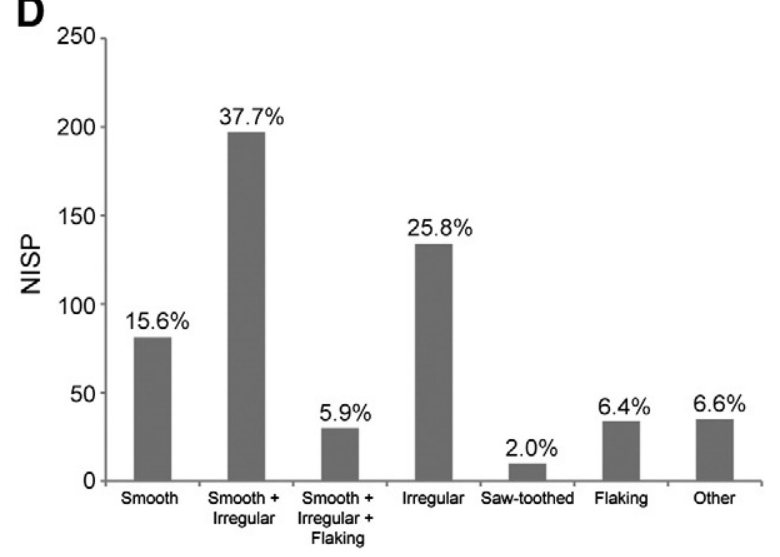

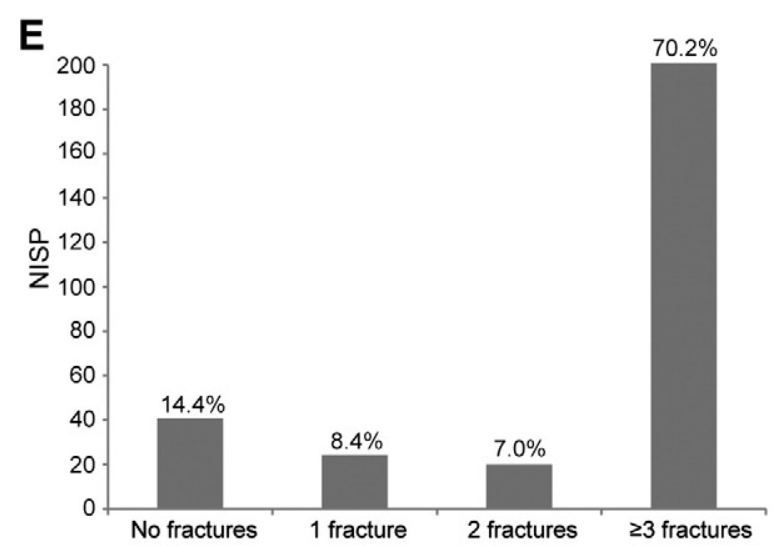

F

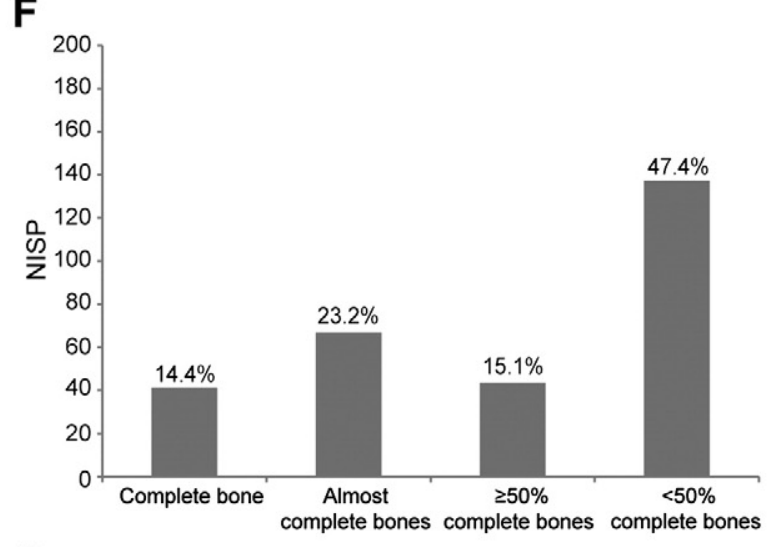

G
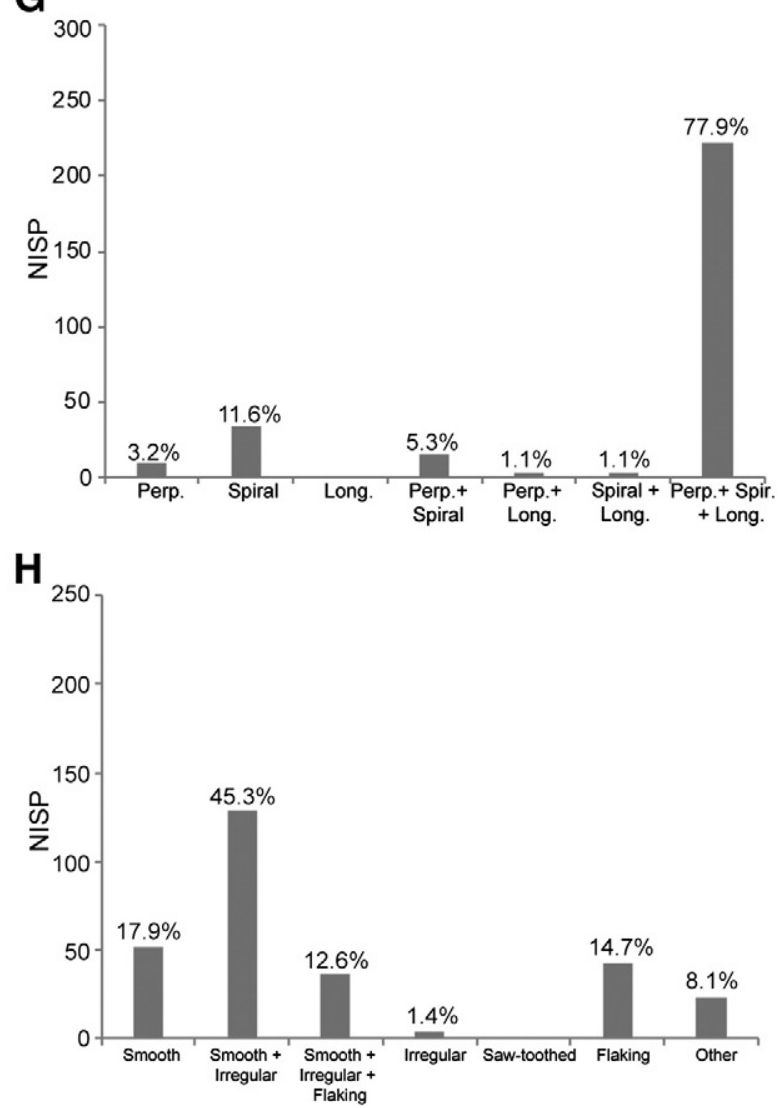

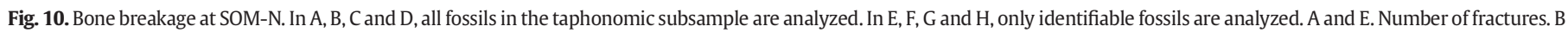
and F. Degree of bone completeness. C and G. Fracture angle. D and H. Fracture surface. 'Other' refers to other fracture combinations too scarce to plot separately. 


\section{Discussion}

\subsection{SOM-N taphonomy}

Coincident with the results of Polonio and López-Martínez (2000), the best represented taxa at SOM-N correspond to the proboscidean Gomphotherium angustidens (11.92\% of the assemblage), ruminants, including Micromeryx sp., Heteroprox sp., Tethytragus sp. and Ruminantia indet. (10.89\%) and the horse Anchitherium cursor (7.34\%) (Table 1). Remains that could not be assigned to a specific taxon or to a specific skeletal element are very abundant (66.10\% and $49.23 \%$, respectively; Table 1 and Table 2), a fact that is mainly due to intense breakage of the bones. Breakage is the most important taphonomic modification observed in the SOM-N bones (Fig. 10, Supplementary Table 5). Bone splinters of $<3 \mathrm{~cm}$ are highly abundant at the site (Fig. 3). A high degree of breakage is also evidenced by the fact that the most abundant identifiable bones involve small-sized elements such as teeth, phalanges and carpal and tarsal bones, i.e., long bones generally did not survive and those that survived are mostly incomplete (Table 2). Remains larger than $8 \mathrm{~cm}$, which should be abundant in an assemblage where proboscidean and equids are dominant taxa, make up only $8.1 \%$ of the assemblage (Fig. 4, Supplementary Table 1). Although teeth are a very abundant element, in most cases they are broken, as demonstrated by the large amount of teeth that could not be identified (Table 2). We agree with Polonio and López-Martínez (2000) in that most of the breakage of the SOM-N bones and teeth took place prior to burial, as demonstrated by the abundance of splinters, the loss of parts of the broken bones from the site and the low amount of only perpendicular breakages (typical of the diagenetic phase). Behrensmeyer $(1982,1991)$ demonstrated that hydraulic transport is not an important cause of fracture of fresh bones. We therefore propose that other agents occurring prior to debris-flow transport were responsible for much of the breakage observed in the SOM-N remains. Trampling must be regarded as an important agent of breakage, above all if we take into account that animals such as the proboscidean Gomphotherium angustidens, with a body mass of more than two metric tons, were very common dwellers of the Madrid Basin during the Middle Miocene. The previously described thin linear marks present on some of the bones (Fig. 12), might have been caused by trampling, but not all the trampled bones necessarily present this kind of marks (M.
S. Domingo, observation at Amboseli National Park). The extent to which predation and scavenging acted as agents of breakage in the SOM-N remains is unknown. We have detected no marks attributable to these agents, but it is plausible that they were erased by other subsequent taphonomic processes (including trampling). In any event, it has been recognized that hydraulic transport can generate some breakage in weathered or dry bones (Behrensmeyer, 1991). A considerable amount of unidentifiable bones display weathering Stage 1, so dry bones were present in the thanacoenoses prior to debris-flow transport. In the literature we found no empirical data describing the taphonomic modification of bones transported by debris flows, but given that these systems are highly energetic, we cannot rule out that some breakage of collagen-depleted bones resulted during transport.

Although pre-burial fragmentation was more significant than postburial breakage, some diagenetic breakage also occurred as demonstrated by the presence of bone collapses and in situ fractures in some skeletal elements (Fig. 13A, B, D, F, G). Elements showing this type of breakage are usually large, identifiable bones.

The SOM-N bones were isolated which indicates that, prior to debris-flow transport, the carcasses were subaerially exposed for a sufficiently long time to enable disarticulation by decay, trampling or scavenging (the bones display no marks by scavengers, but it is possible that they disarticulated some carcasses without leaving signs on the bones). Hill and Behrensmeyer (1984) studied the sequence of disarticulation in several African herbivores and determined that complete disarticulation was reached 5 years after the death of the animal. The lack of associated remains may be indicative that, in the original thanatocoenoses, the elements were already disassociated, but it is also feasible that the skeletal elements were scattered by the debrisflow episodes. Weathering stage is used as a tool to infer time elapsed from death until burial. At SOM-N, most of the bones display weathering Stages 0 or 1 (Fig. 8, Supplementary Table 3), which is indicative of a maximum time of exposure of 3 years before burial (Behrensmeyer, 1978). Additionally, a few bones display weathering Stages 2 and 3, which are indicative of times of exposure $>2$ years and then 4 years before burial, respectively. Furthermore, we cannot rule out the possibility that some of the SOM-N bones were subjected to intense weathering, but that the subsequent taphonomic processes erased the weathering signatures from the bone surface. The concurrence of elements with

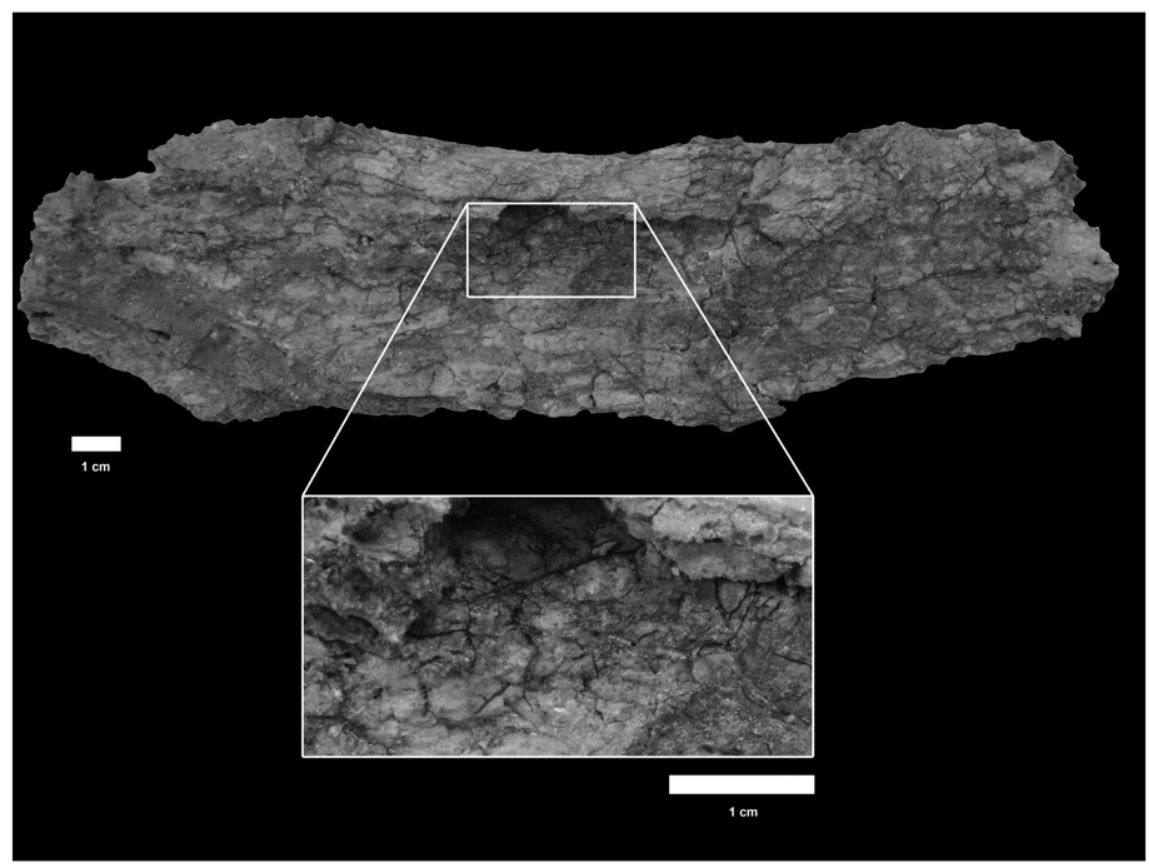

Fig. 11. Unidentifiable fossil SOM-N'04 2042 showing abundant modern root marks. 
weathering Stages 0 and 1 , together with elements exhibiting weathering Stages 2 and 3, would suggest that debris-flow events did not have an annual character, but were rather more separated in time. This is in agreement with the sedimentological evidence (i.e., embayed quartz grains, low charge beidellites), which points to sedimentation pauses that enabled the weak development of soils in these deposits (Fesharaki et al., 2015). At SOM-N, weathering Stage 1 and above are more abundant in unidentifiable bone fragments than in identifiable bones, which usually display weathering Stage 0 (Fig. 8B, C). This seems reasonable, as more weathered bones are more prone to breakage.

Abraded bone surfaces and abraded bone fractures are abundant in the SOM-N assemblage, although unidentifiable bones display more smoothening and polishing than identifiable bones (Fig. 9B, C, Supplementary Table 4). Abrasion damage has been most commonly attributed to hydraulic transport, but other agents such as wind, weathering, trampling, chewing or chemical and physical erosion during digestion can abrade bone surfaces and fractures (Behrensmeyer, 1991). Abrasion produced by sedimentary particles bombarded by wind tends to be localized in the area being sand-blasted (Lyman, 1994). This is not the case of the SOM-N remains, where abrasion damage is not located in specific areas or on specific surfaces. Bones that have been digested display rounding and polishing produced by digestive acids, but this feature is usually accompanied by other taphonomic modifications, such as the exposure of spongy bone in articular areas and thinning of the bone cortex (see Domingo M.S. et al., 2012 and references therein). We did not detect these features in the SOM-N bones. Rather, we consider that abrasion in the SOM-N remains was caused during trampling or hydraulic transport. As previously indicated, abrasion is a proxy of the intensity and/or time period of interaction with sediment, but not necessarily of distance of transport (Behrensmeyer, 1991). The bones displaying more extreme abrasion stages at SOM-N are unidentifiable, which seems reasonable, as they would have been exposed for a longer time prior to burial and were therefore subjected to intense trampling; moreover, these bones were most likely dry when transported by the debris flow and, were consequently more vulnerable to further abrasion and breakage than fresh bones.

Analysis of the morphology of the bones can provide information on the sorting of the bones during transport. The four morphological categories are present at SOM-N (Fig. 5, Supplementary Table 2), which is indicative of the poor sorting capacity of the debris flows that transported and buried the elements; this was also observed in other debris-flow deposits (e.g., Britt et al., 2009).

As for the spatial distribution of fossils in the deposits, there appear to be two distinct fossil-rich levels towards the North in the $\mathrm{X}-\mathrm{Z}$ cross section (Fig. 6B). No levels are visible in the Y-Z section (Fig. 6C). Elez (2005) suggested that the SOM-N deposits presented several levels, alternately rich and poor in fossils. It is possible that the amount of fossil remains that we employed in the spatial distribution analysis is so large compared to the one analyzed by Elez (2005) that the levels are not

A
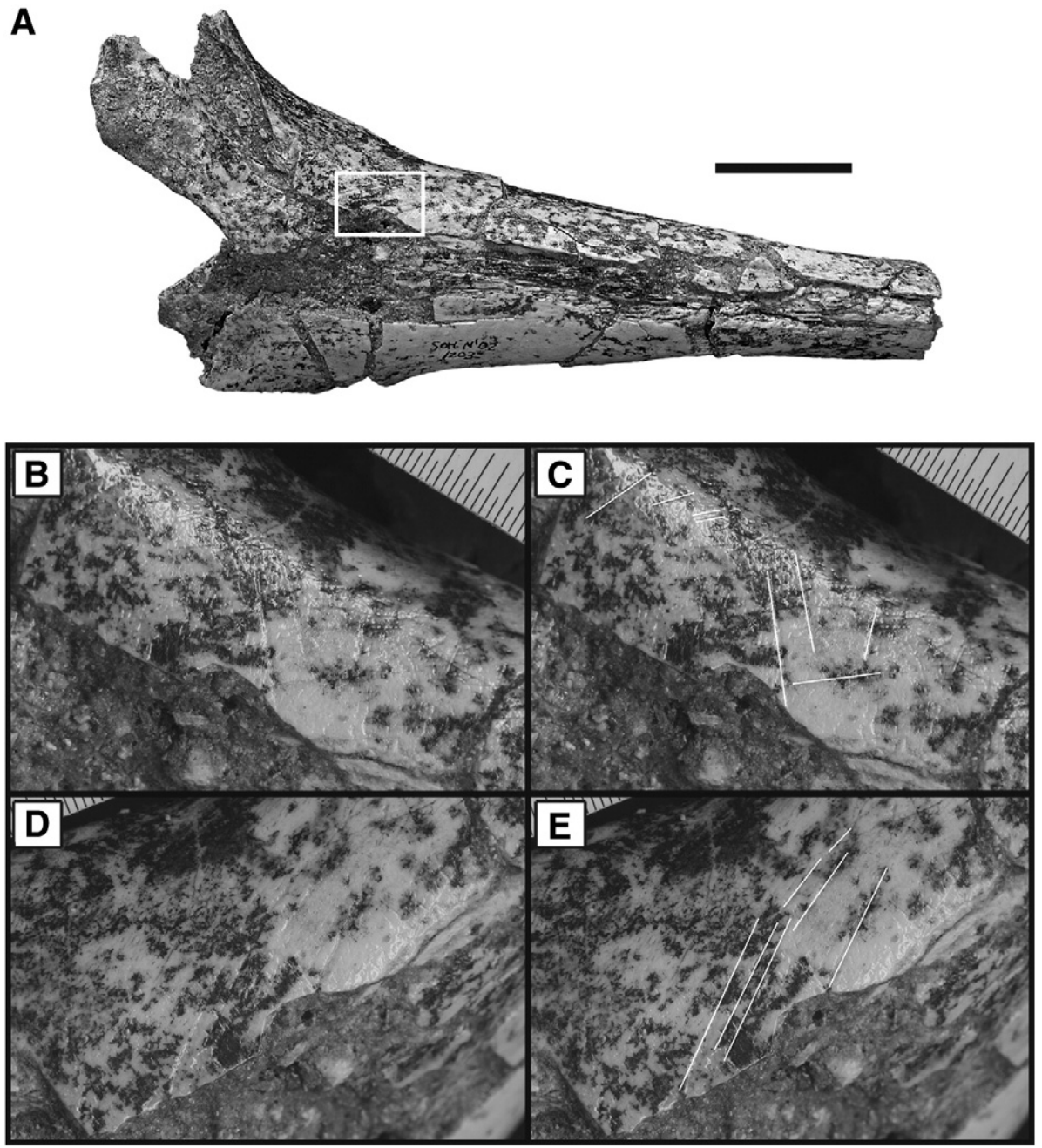

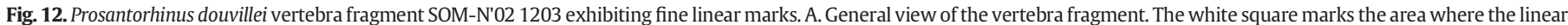

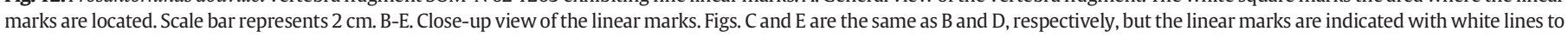
facilitate their observation. Major divisions in the scale shown in B, C, D and E represent $1 \mathrm{~mm}$. 
easily recognizable. However, it is worth highlighting that when the sample is reduced by excluding unidentifiable bone fragments, levels are still unrecognizable (Supplementary Fig. 1). Future three-dimensional analyses of the SOM-N coordinates data will shed more light on the geometry of the deposits and will facilitate recognition of different fossiliferous levels, if present.

Contrary to Polonio and López-Martínez (2000), who identified a trend alignment of the bones on the north-south axis, the rose diagram drawn in the present study suggests that SOM-N long bones $(>10 \mathrm{~cm})$ are randomly oriented (Fig. 7). The mean plunge of bones calculated in our study, $17.64^{\circ}$, is very close to that of $15^{\circ}$ estimated by Polonio and López-Martínez (2000).
Based on the taphonomic evidence, we suggest that the SOM-N assemblage is made up of a mixture of elements with different breakage, abrasion and weathering states, but two endmembers can be suggested: on the one hand, splinters appear to have been the result of elements that were exposed over a longer time period prior to burial and subject to intense breakage and abrasion by trampling and weakened by loss of collagen, a fact that gave rise to further breakage and abrasion during debris-flow transport. On the other hand, we also recovered relatively well preserved skeletal elements (Fig. 13) that would seem to correspond to carcasses that underwent a shorter time of exposure (although sufficiently long to reach complete disarticulation), and lower levels of alteration prior to and during debris-flow transport.

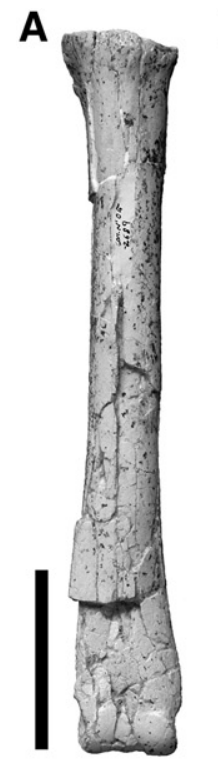

E

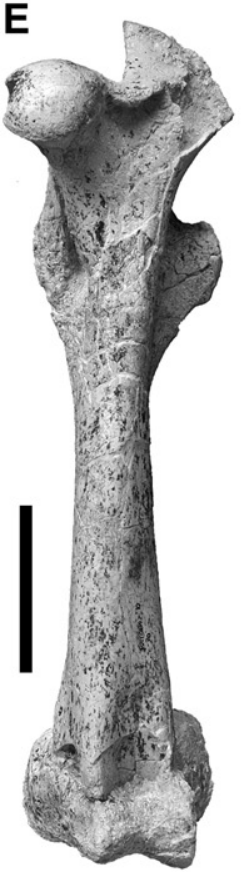

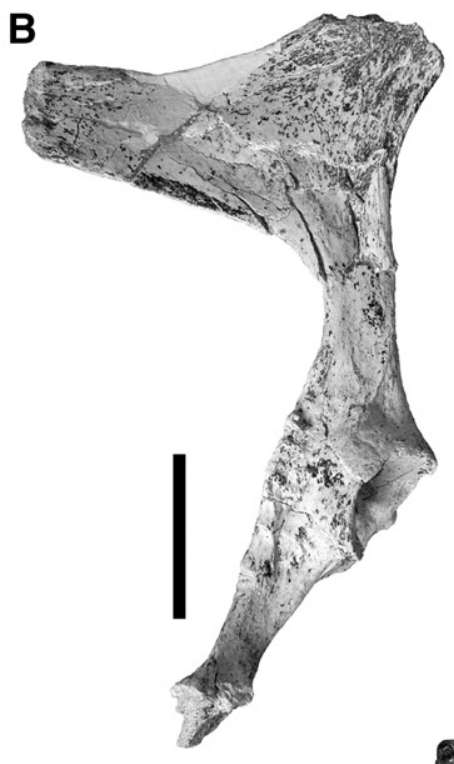
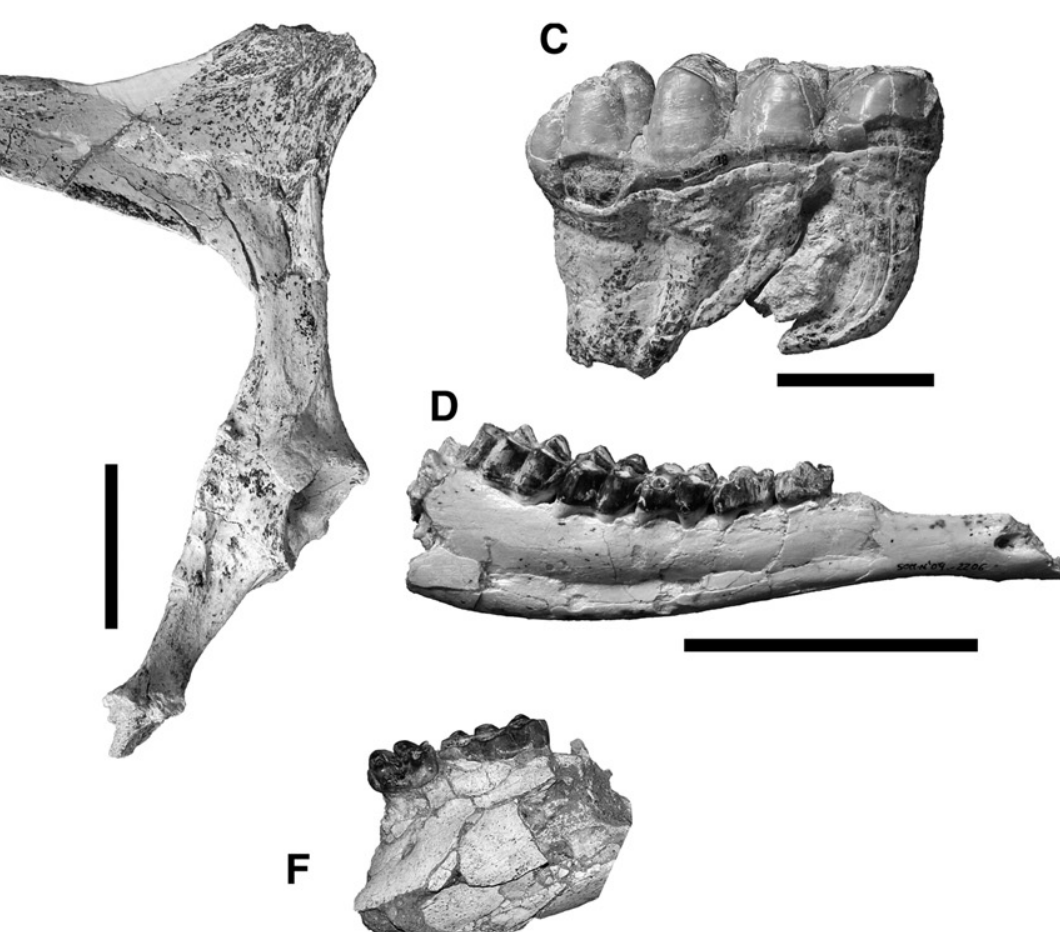

(1)
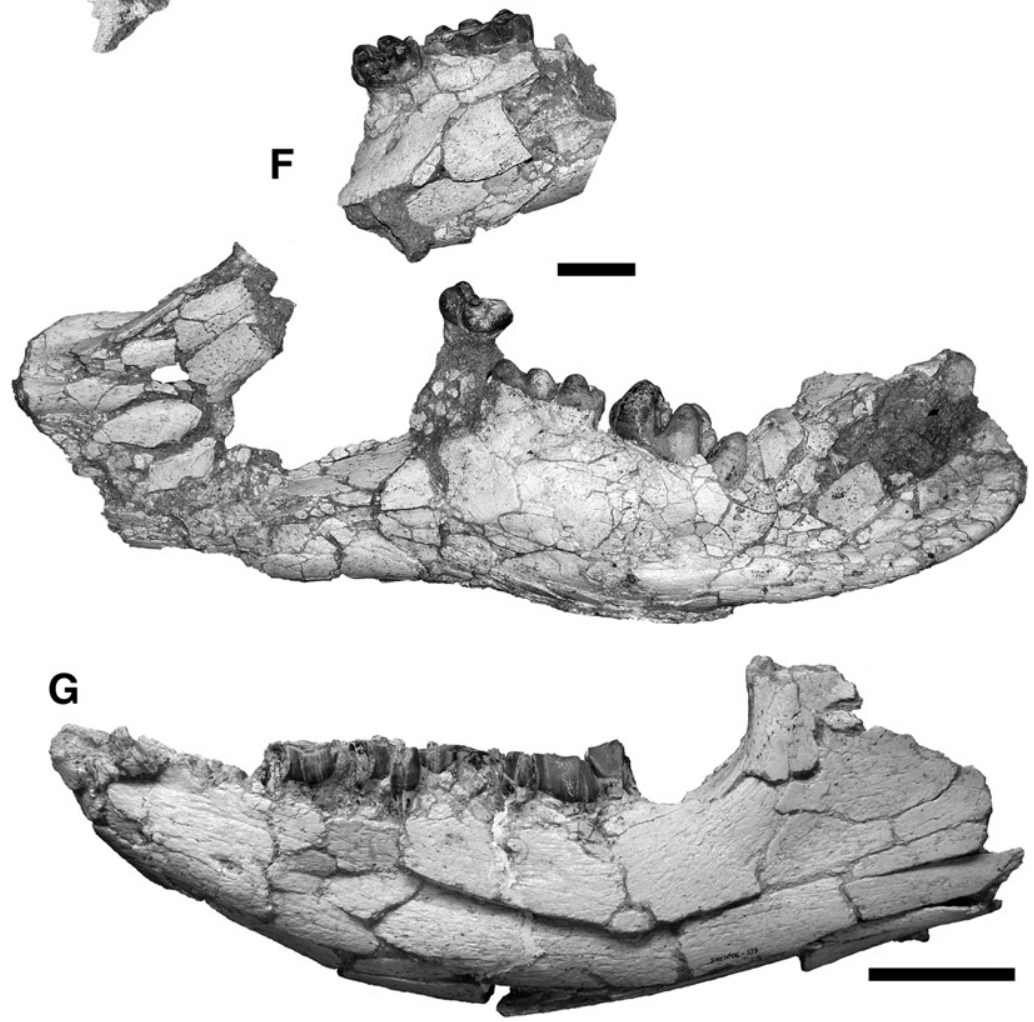

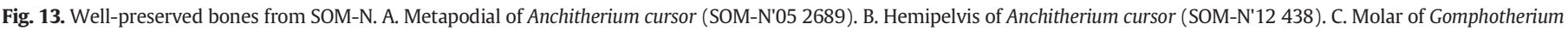

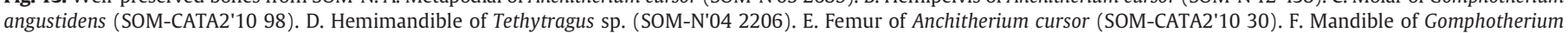

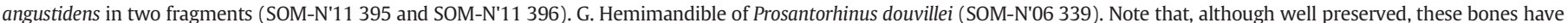

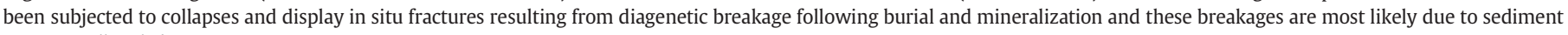
pressure. All scale bars represent $5 \mathrm{~cm}$. 
Table 3

Taphonomic characteristics of debris-flow hosted assemblages.

\begin{tabular}{|c|c|c|c|c|c|}
\hline \multirow[b]{2}{*}{ Locality } & \multicolumn{5}{|l|}{ Mammal-dominated } \\
\hline & Somosaguas-North & Paşalar & $\begin{array}{l}\text { Vallparadís Estació } \\
\text { (Layer 7) }\end{array}$ & Collecurti & La Paz \\
\hline Country & Spain & Turkey & Spain & Italy & Uruguay \\
\hline Age & Middle Miocene & Middle Miocene & Early Pleistocene & Early Middle Pleistocene & $\begin{array}{l}\text { Early Middle } \\
\text { Pleistocene }\end{array}$ \\
\hline Matrix & $\begin{array}{l}\text { Matrix-supported } \\
\text { coarse sandstones } \\
\text { and fine } \\
\text { conglomerate }\end{array}$ & Poorly sorted sands and gravels & $\begin{array}{l}\text { Small-sized pebbles } \\
\text { in a } \\
\text { matrix-supported } \\
\text { mud }\end{array}$ & $\begin{array}{l}\text { Clast-supported to matrix-supported, gravel } \\
\text { with sandy, silty clay matrix }\end{array}$ & $\begin{array}{l}\text { Matrix-supported } \\
\text { diamictite (matrix } \\
\text { is predominantly } \\
\text { clayey) }\end{array}$ \\
\hline $\begin{array}{l}\text { Taxonomic } \\
\text { representation }^{\mathrm{a}}\end{array}$ & MU_Mu & MU_Mu & MU_Mu & MU_Mo & MU_Mu \\
\hline Type of death & Unknown & Attritional & Not reported & Mass mortality event (unrelated to debris flow) & Not reported \\
\hline NISP & 6592 & Not reported & 3234 & 496 & 130 \\
\hline $\begin{array}{l}\text { NISP } \\
\quad \text { (unidentifiable) }\end{array}$ & 4357 & Not reported & 726 & 53 & $\begin{array}{l}\text { Unidentified } \\
\text { fragments are very } \\
\text { abundant }\end{array}$ \\
\hline MNI & Not estimated & Not reported & Not reported & 24 & 130 \\
\hline $\begin{array}{l}\text { Dominant age } \\
\text { class }\end{array}$ & Not estimated & $\begin{array}{l}\text { Adults are more abundant in } \\
\text { medium-sized mammals. Juveniles are } \\
\text { equally or more abundant than adults } \\
\text { in mega-herbivores. }\end{array}$ & Not reported & Adult & Not reported \\
\hline Bone orientation & $\begin{array}{l}\text { No trend } \\
\text { alignment }\end{array}$ & $\begin{array}{l}\text { Variable in the different sedimentary } \\
\text { facies }\end{array}$ & No trend alignment & $\begin{array}{l}\text { Two trend alignments, horizontal to } \\
\text { subhorizontal plunges. }\end{array}$ & $\begin{array}{l}\text { No trend } \\
\text { alignment }\end{array}$ \\
\hline $\begin{array}{l}\text { Representation of } \\
\text { bones relative } \\
\text { to transport }\end{array}$ & $\begin{array}{l}\text { All types of } \\
\text { elements present }\end{array}$ & Not reported & Not reported & $\begin{array}{l}\text { Hippopotamus sample: larger representation of } \\
\text { less easily transportable elements; } \\
\text { Non-Hippopotamus sample: larger } \\
\text { representation of easily transportable element }\end{array}$ & $\begin{array}{l}\text { All types of } \\
\text { elements present }\end{array}$ \\
\hline $\begin{array}{l}\text { Dominant } \\
\text { articulation } \\
\text { mode }\end{array}$ & Isolated & Isolated & Isolated & Associated & Isolated \\
\hline $\begin{array}{l}\text { Dominant } \\
\text { weathering } \\
\text { stage }\end{array}$ & 0 and 1 & $\begin{array}{l}\text { All weathering stages represented in } \\
\text { unidentifiable bones. WS } 0 \text { and } 1 \text { are } \\
\text { more abundant in identifiable bones. }\end{array}$ & 0 and 1 & $\begin{array}{l}0 \text { (but more intense in non-Hippopotamus } \\
\text { sample) }\end{array}$ & 0 and $1-2$ \\
\hline $\begin{array}{l}\% \text { Abraded } \\
\text { remains }\end{array}$ & 82.3 & 90.0 & Not reported & $\begin{array}{l}0.4 \% \text { of the Hippopotamus sample; } 10 \% \text { of the } \\
\text { non-Hippopotamus sample }\end{array}$ & 5.0 \\
\hline $\begin{array}{l}\text { \% Broken } \\
\text { remains }\end{array}$ & 93.3 & Extreme fragmentation & $\begin{array}{l}\text { Most of the bones } \\
\text { are broken }\end{array}$ & Mostly post-depositional breakage & 70.0 \\
\hline $\begin{array}{l}\text { \% Carnivore } \\
\text { modified }\end{array}$ & 0 & 0 & Abundant marks & 0 & Not reported \\
\hline $\begin{array}{l}\text { \% Trampling } \\
\text { marks }\end{array}$ & $<1.0$ & 0 & Not reported & 0 & Not reported \\
\hline $\begin{array}{l}\text { Site category } \\
\text { (after Britt et } \\
\text { al., 2009) }\end{array}$ & 1 & 1 & Not reported & 4 & 1 \\
\hline Reference & This study & $\begin{array}{l}\text { Andrews and Ersoy (1990), Andrews } \\
\text { (1995) }\end{array}$ & $\begin{array}{l}\text { Madurell-Malapeira } \\
\text { et al. (2011) }\end{array}$ & Mazza and Ventra (2011) & $\begin{array}{l}\text { Corona et al. } \\
(2012)\end{array}$ \\
\hline
\end{tabular}

${ }^{\mathrm{a}} \mathrm{MO}=$ Monotaxic (only one taxon at the fossil site), MU_Mo = Multitaxic_Monodominant (multiple taxa but one taxon dominates and account for $50 \%$ or more of the NISP or the MNI), MU_Mu = Multitaxic_multidominant (multiple taxa but two or more taxa dominates and account for 50\% or more of the NISP or the MNI).

b Origination mode of debris-flow hosted assemblages after Britt et al. (2009): 1. Debris-flow transport and burial of pre-existing thanatocoenoses. 2. In situ burial of a pre-existing thanatocoenosis by a debris flow. 3. Death and burial of the biocoenose by a debris flow. 4. Combinations of 1-3.

It is difficult to infer the agent responsible for the death of the individuals in a fossiliferous assemblage such as SOM-N, where breakage, transport and scattering have been intense. The taphonomical evidence at least enables us to ascertain that the debris-flow episodes were not the cause of mortality. Had a debris flow been the main agent of mortality, the assemblage would have shown mass-mortality taphonomic signatures such as the presence of articulated skeletons and non-altered bones, as a consequence of very rapid burial, as well as catastrophic or 'L-shaped' age profiles (Lyman, 1994).

We have not been able to quantify the amount of juvenile vs adult individuals present at SOM-N, as this information is not recorded in the field notes and because we have not conducted a direct observation of the entire fossil collection. Nonetheless, from the start of the excavations, researchers observed the presence of abundant juvenile bones (Polonio and López-Martínez, 2000). Isolated decidual teeth are abundant at SOM-N, but their presence in a fossil site cannot be used as evidence of elevated death rates for juveniles as these teeth are shed during an animal's lifetime and do not imply its death. Nevertheless, we have observed a large amount of skeletal elements with unfused epiphyses and some maxillae and mandibles with decidual teeth, which together with the presence of juvenile osseous microstructures detected in histological sections (Cuezva and Elez, 2000), point to the death of juvenile individuals.

As previously indicated, a savanna biome has been inferred at SOM$\mathrm{N}$, which presented a tropical semiarid climatic regime and a very pronounced hydrological seasonality, with an alternation of long dry periods and short wet periods (Cuevas-González, 2005; Hernández Fernández et al., 2006; Carrasco et al., 2008; Domingo et al., 2009; García Yelo et al., 2014). Debris flows result from slope failure and are triggered by diverse causes including rainfall, seismic activity, volcanism, plant denudation or changes in surface and substrate cohesiveness resulting from altered ground water flow patterns (Eberth et al. 2006 and references therein). In the semiarid environment registered at SOM-N, we propose that debris-flow events were generated during times of intense seasonal rainfall. Fluvial facies are almost absent in the Somosaguas fossiliferous levels (Cuevas-González, 2005) and no aquatic fauna, such as fish, amphibians or crocodiles (the turtles from SOM-N are terrestrial), has been recovered (Domingo et al., 2009), which implies a shortage of permanent fresh-water bodies in this area. Polonio and López-Martínez (2000) suggested that droughts 


\begin{tabular}{|c|c|c|c|c|c|c|}
\hline & Dinosaur-dominated & & & & & \\
\hline Jirau & $\begin{array}{l}\text { Mother's } \\
\text { Day Quarry }\end{array}$ & Jimbo Quarry & Dalton Wells & Puesto Díaz Quarry & Bleriot Ferry & Fox Coulee \\
\hline Brazil & United States & United States & United States & Argentina & Canada & Canada \\
\hline Late Pleistocene & Upper Jurassic & Upper Jurassic & Lower Cretaceous & Lower Cretaceous & Upper Cretaceous & Upper Cretaceous \\
\hline $\begin{array}{l}\text { Conglomerate } \\
\text { supported by } \\
\text { feldspatic } \\
\text { clayey-sandy } \\
\text { matrix }\end{array}$ & $\begin{array}{l}\text { Massive, } \\
\text { sandy siltstone }\end{array}$ & $\begin{array}{l}\text { Muddy-silt } \\
\text { matrix- Unit A } \\
\text { (debris flow) }\end{array}$ & $\begin{array}{l}\text { Massive-to-vaguely } \\
\text { graded, } \\
\text { sandy to pebbly } \\
\text { mudstone }\end{array}$ & Massive muddy sandstones & $\begin{array}{l}\text { Poorly sorted } \\
\text { organic-fragment-rich } \\
\text { mudstone }\end{array}$ & $\begin{array}{l}\text { Poorly sorted } \\
\text { organic-fragment-rich } \\
\text { mudstone }\end{array}$ \\
\hline MU_Mo & MU_Mo & MO & MU_Mu & MO & MU_Mo & MU_Mo \\
\hline $\begin{array}{l}\text { Attritional }+ \text { mass } \\
\text { mortality events } \\
\text { (unrelated to debris } \\
\text { flow) }\end{array}$ & $\begin{array}{l}\text { Mass mortality event } \\
\text { (unrelated to debris } \\
\text { flow) }\end{array}$ & $\begin{array}{l}\text { Only one } \\
\text { individual }\end{array}$ & $\begin{array}{l}\text { Attritional }+ \text { mass } \\
\text { mortality events } \\
\text { (unrelated to debris } \\
\text { flow) }\end{array}$ & $\begin{array}{l}\text { Mass mortality event } \\
\text { (unrelated to debris } \\
\text { flow) }\end{array}$ & $\begin{array}{l}\text { Mass mortality event } \\
\text { (unrelated to debris } \\
\text { flow) }\end{array}$ & $\begin{array}{l}\text { Mass mortality event } \\
\text { (unrelated to debris } \\
\text { flow) }\end{array}$ \\
\hline 1405 & 987 (only identifiable) & Not reported & 4211 & 159 & 1567 & 233 \\
\hline 1303 & Not reported & Not reported & $\begin{array}{l}\text { Unidentified bone } \\
\text { fragments } \\
\text { dominate the } \\
\text { assemblage }\end{array}$ & 33 & $\begin{array}{l}\text { Three fragments for } \\
\text { every two identifiable } \\
\text { elements }\end{array}$ & Not reported \\
\hline 48 & 15 (Diplodocoidea) & 1 & 71 & 3 & 9 (Edmontosaurus) & Not reported \\
\hline Adult & Juvenile & Not reported & Subadults & Adult & Adult & Juvenile \\
\hline Not reported & $\begin{array}{l}\text { Trend alignment; } \\
\text { subhorizontal plunge }\end{array}$ & $\begin{array}{l}\text { Trend } \\
\text { alignment }\end{array}$ & $\begin{array}{l}\text { No trend alignment; } \\
\text { horizontal to } \\
\text { subhorizontal } \\
\text { plunges }\end{array}$ & $\begin{array}{l}\text { Large bones show trend } \\
\text { alignment; small bones } \\
\text { show random orientation }\end{array}$ & $\begin{array}{l}\text { Trend alignment; } \\
\text { horizontal to } \\
\text { subhorizontal plunges }\end{array}$ & $\begin{array}{l}\text { Trend alignment; } \\
\text { horizontal to } \\
\text { subhorizontal plunges }\end{array}$ \\
\hline $\begin{array}{l}\text { Larger representation of } \\
\text { non-easy to transport } \\
\text { elements }\end{array}$ & $\begin{array}{l}\text { Predominance of } \\
\text { elements with } \\
\text { intermediate transport } \\
\text { potential }\end{array}$ & Not reported & $\begin{array}{l}\text { Predominance of } \\
\text { elements } \\
\text { with complex shapes; } \\
\text { reduced } \\
\text { occurrence of the most } \\
\text { easily } \\
\text { to transport } \\
\text { elements }\end{array}$ & $\begin{array}{l}\text { Mix of easily transported } \\
\text { and non-easily transported } \\
\text { elements }\end{array}$ & Not reported & Not reported \\
\hline Isolated & $\begin{array}{l}\text { Isolated and some } \\
\text { associations }\end{array}$ & Associated & $\begin{array}{l}\text { Isolated but some } \\
\text { associations }\end{array}$ & Isolated & Isolated & Isolated \\
\hline $\begin{array}{l}3 \text { (but all stages } \\
\text { present) }\end{array}$ & 0 & Not reported & 0 and $4-5$ & Not reported & Minimal weathering & Minimal weathering \\
\hline 96.0 & 10.0 & Not reported & $\begin{array}{l}\text { Common } \\
\text { feature }\end{array}$ & $\begin{array}{l}\text { Low to moderate } \\
\text { abrasion }\end{array}$ & $\begin{array}{l}\text { Moderate } \\
\text { abrasion }\end{array}$ & $\begin{array}{l}\text { Minimal } \\
\text { abrasion }\end{array}$ \\
\hline 82.0 & 45.0 & Not reported & 97.0 & Not reported & $>90.0$ & $>90.0$ \\
\hline 1.9 & Very low & 0 & 1 & Not reported & $>10.0$ & Not reported \\
\hline 15.9 & Not reported & Not reported & $>6.0$ & Not reported & $>15.0$ & Not reported \\
\hline 1 & 2 & 1 & 1 & 1 & 2 & 2 \\
\hline $\begin{array}{l}\text { Araújo-Júnior et al. } \\
\text { (2013) }\end{array}$ & $\begin{array}{l}\text { Myers and } \\
\text { Storrs (2007); Storrs } \\
\text { et al. (2013) }\end{array}$ & $\begin{array}{l}\text { Lovelace } \\
\text { (2006) }\end{array}$ & $\begin{array}{l}\text { Eberth et al. (2006); } \\
\text { Britt et al. (2009) }\end{array}$ & Garrido and Salgado (2015) & Evans et al. (2015) & Evans et al. (2015) \\
\hline
\end{tabular}

could have constituted a major mortality agent. In view of the climatic regime inferred at SOM-N and the scarcity of stable and long term aquatic conditions in the area, we agree that drought could have played a significant role in the death of individuals -especially juveniles- in the Madrid Basin. In a drought scenario, there would have been intense trampling of the bones of carcasses concentrated around waterholes during the dry season.

To sum up, the present taphonomic study involves the following steps in the formation of the SOM-N assemblage: 1) death of mammals due to different causes (droughts probably played a major role); 2) carcasses were exposed a sufficiently long time to allow decay, defleshing and complete disarticulation; 3 ) bones underwent different degrees of breakage and abrasion (prior to debris-flow transport) and weathering, depending on the duration of exposure of the carcasses that incorporated in the thanatocoenoses; 4 ) heavy rainfalls occurred, likely displaying multiannual periodicity, triggering a debris flow that incorporated and buried bones in different preservation states. Debris-flow transport could produce further breakage and abrasion of weathered and dry bones; 5) compaction of skeletal elements and percolation of Mn laden fluids; 6) in modern times, plant roots altered the surface of some bones. As previously mentioned, SOM-N is the result of several debris-flow episodes, and steps 1 to 4 therefore occurred on repeated occasions.
The fauna represented at SOM-N consists of taxa that are well represented in other Aragonian fossil sites from the Madrid Basin (Peláez-Campomanes et al., 2003; Domingo L. et al., 2012a) and they can therefore be considered as common dwellers of the area. We consider the faunal accumulation at SOM-N as parautochthonous (sensu Behrensmeyer and Hook, 1992), as bones were transported, but remain within the habitat area.

\subsection{Comparison with other debris-flow hosted vertebrate fossil sites}

We surveyed the literature to compile taphonomic data from other debris-flow vertebrate localities; this information is shown in Table 3. We reported only the studies providing detailed taphonomic information.

There is a remarkable scarcity of mammalian-dominated fossil sites hosted in debris-flow deposits (Table 3). Apart from SOM-N, in the literature we only found five localities for the whole Cenozoic, Paşalar (Andrews and Ersoy, 1990; Andrews, 1995) and SOM-N constituting the only pre-Pleistocene sites (both localities are dated from the Middle Miocene). Debris-flow sites dominated by dinosaur remains are more abundant than mammalian-dominated sites (Table 3 ). It is worth highlighting that, in her analysis of the frequencies of bonebeds as a function of the depositional environment, Eberth et al. (2007b) showed 
Table 3 (continued)

\begin{tabular}{|c|c|c|c|c|c|c|}
\hline & Dinosaur-dominated & & & & Vertebrate-dominated & \\
\hline Locality & Prehistoric Park & Sun River Bonebed & Kundur & Blagoveschensk & Huizachal Canyon & Ukhaa Tolgod \\
\hline Country & Canada & United States & Russia & Russia & Mexico & Mongolia \\
\hline Age & Upper Cretaceous & Upper Cretaceous & Upper Cretaceous & Upper Cretaceous & Middle Jurassic & Upper Cretaceous \\
\hline Matrix & $\begin{array}{l}\text { Poorly sorted } \\
\text { organic-fragment-rich } \\
\text { mudstone }\end{array}$ & $\begin{array}{l}\text { Calcareous clasts in a } \\
\text { matrix of silty mud and } \\
\text { sand grains }\end{array}$ & $\begin{array}{l}\text { Muddy matrix with } \\
\text { scattered coarse sand } \\
\text { particles and pebbles. }\end{array}$ & $\begin{array}{l}\text { Massive claystone } \\
\text { with dispersed } \\
\text { granules }\end{array}$ & $\begin{array}{l}\text { Mud-rich matrix } \\
\text { supported unsorted } \\
\text { volcaniclastic intraclasts }\end{array}$ & $\begin{array}{l}\text { Structureless } \\
\text { sandstones }\end{array}$ \\
\hline $\begin{array}{l}\text { Taxonomic } \\
\text { representation }^{\mathrm{a}}\end{array}$ & MU_Mo & MU-Mo & MU_Mo & MU_Mo & MU_Mu & MU_Mu \\
\hline Type of death & $\begin{array}{l}\text { Mass mortality event } \\
\text { (unrelated to debris } \\
\text { flow) }\end{array}$ & $\begin{array}{l}\text { Mass mortality event } \\
\text { (unrelated to debris } \\
\text { flow) }\end{array}$ & Not reported & Attritional & Not reported & $\begin{array}{l}\text { Mass mortality } \\
\text { event (caused } \\
\text { by the debris } \\
\text { flow) }\end{array}$ \\
\hline NISP & 1893 & 592 & Not reported & Not reported & 8095 & Not reported \\
\hline $\begin{array}{l}\text { NISP } \\
\quad \text { (unidentifiable) }\end{array}$ & $\begin{array}{l}\text { Four fragments for } \\
\text { every identifiable } \\
\text { remains }\end{array}$ & 55 & Not reported & Not reported & $\begin{array}{l}52.1 \% \text { (based on a sample } \\
\text { of } 2035 \text { specimens) }\end{array}$ & Not reported \\
\hline MNI & 2 (Edmontosaurus) & 8 & Not reported & Not reported & Not reported & 505 \\
\hline $\begin{array}{l}\text { Dominant age } \\
\text { class }\end{array}$ & Adult & Juvenile & Juvenile and adult & $\begin{array}{l}\text { Juvenile and } \\
\text { subadult }\end{array}$ & Not reported & Not reported \\
\hline Bone orientation & $\begin{array}{l}\text { No trend alignment; } \\
\text { horizontal to } \\
\text { subhorizontal plunges }\end{array}$ & $\begin{array}{l}\text { Trend alignment; } \\
\text { random plunges }\end{array}$ & $\begin{array}{l}\text { Trend alignment; } \\
\text { subhorizontal plunge }\end{array}$ & $\begin{array}{l}\text { No trend alignment; } \\
\text { subhorizontal } \\
\text { plunge }\end{array}$ & Trend alignment & Not reported \\
\hline $\begin{array}{l}\text { Representation of } \\
\text { bones relative to } \\
\text { transport }\end{array}$ & Not reported & $\begin{array}{l}\text { Larger representation of } \\
\text { non-easily transported } \\
\text { elements }\end{array}$ & Not reported & $\begin{array}{l}\text { Predominance of } \\
\text { non-easily } \\
\text { transported } \\
\text { elements }\end{array}$ & Not reported & Not reported \\
\hline $\begin{array}{l}\text { Dominant } \\
\text { articulation } \\
\text { mode }\end{array}$ & Isolated & Isolated & Articulated & Isolated & Isolated & Articulated \\
\hline $\begin{array}{l}\text { Dominant } \\
\text { weathering } \\
\text { stage }\end{array}$ & Minimal weathering & 0 & Not reported & 0 & Not reported & Minimal weathering \\
\hline $\begin{array}{c}\text { \% Abraded } \\
\text { remains }\end{array}$ & Minimal abrasion & 31.4 & Not reported & Not reported & Common feature & Minimal abrasion \\
\hline \% Broken remains & $>90.0$ & 28.0 & Not reported & $\begin{array}{l}\text { Abundant broken } \\
\text { remains }\end{array}$ & $\begin{array}{l}\text { Most of the specimens are } \\
\text { broken }\end{array}$ & Not reported \\
\hline $\begin{array}{l}\text { \% Carnivore } \\
\text { modified }\end{array}$ & $<1.0$ & Low & Not reported & $<2.0$ & Not reported & Not reported \\
\hline $\begin{array}{l}\text { \% Trampling } \\
\text { marks }\end{array}$ & Not reported & Moderate & Not reported & 0 & Not reported & Not reported \\
\hline $\begin{array}{l}\text { Site category (after } \\
\text { Britt et al., } \\
\text { 2009) }^{\text {b }}\end{array}$ & 2 & 1 & 2 & 1 & 4 & 3 \\
\hline Reference & Evans et al. (2015) & $\begin{array}{l}\text { Scherzer and Varricchio } \\
(2010)\end{array}$ & $\begin{array}{l}\text { Van Itterbeeck et al. } \\
\text { (2005) }\end{array}$ & Lauters et al. (2008) & Fastovsky et al. (1995) & $\begin{array}{l}\text { Dashzeveg et al. } \\
(1995), \text { Loope et al. } \\
(1998,1999)\end{array}$ \\
\hline
\end{tabular}

that bonebeds found within the category 'Alluvial-fan/debris-flow/ mass-sediment deposits' were very scarce in the fossil record and only eolian deposits hosted a smaller amount of fossil vertebrate assemblages.

Britt et al. (2009) categorized debris-flow sites as a function of their mode of origination as assemblages formed by: 1) debris-flow reworking and burial of pre-existing thanatocoenoses; 2 ) in situ burial of a pre-existing thanatocoenosis by a debris flow; 3 ) death and burial of the biocoenoses by debris flow; 4 ) combinations of $1-3$. Most of the debris-flow hosted fossil sites included in Table 3 belong to categories 1 and 2. The SOM-N taphonomic evidence demonstrates that the assemblage belongs to category 1 .

In view of the varied taphonomic histories that remains present prior to debris-flow transport (Britt et al. 2009), it is unsurprising that these types of sites only have a few features in common. The shared features of debris-flow hosted localities suggested by Britt et al. (2009) mainly refer to the geological and spatial taphonomical data. SOM-N displays some of these features: the deposits are massive and poorlysorted coarse-grained sediments, fossil specimens are mostly flatlying, with a smaller amount subvertically oriented, and elongate elements do not show preferential orientations.

SOM-N shares further taphonomic features with other category 1 sites reported in Table 3, specifically, with Paşalar (Turkey), La Paz
(Uruguay), Jirau (Brazil), Dalton Wells (USA) and Blagoveschensk (Russia), such as the abundance of isolated elements and of heavily broken remains (Andrews and Ersoy, 1990; Andrews, 1995; Lauters et al., 2008; Britt et al., 2009; Corona et al., 2012; Araújo-Júnior et al., 2013). Among these sites, abrasion can be considered as an important feature at SOM-N, Paşalar, Jirau and Dalton Wells. Other category 1 sites, however, display important dissimilarities. For example, at the Upper Cretaceous lambeosaurine-dominated locality of Sun River Bonebed (Montana, United States), only $28 \%$ of the assemblage shows some degree of breakage (Table 3) (Scherzer and Varricchio, 2010). These authors indicated that the elevated clay content of the debris flow that formed the Sun River Bonebed assemblage likely cushioned large bones, thus preventing extreme breakage (Scherzer and Varricchio, 2010).

Whereas category 1 assemblages show variable taxonomic representations (monotaxic, multitaxic-monodominant and multitaxicmultidominant), category 2 assemblages are always multitaxicmonodominant (Table 3), which indicates that although more than one genus or species are present, one taxon dominates and accounts for $50 \%$ or more of the NISP or MNI (Eberth et al., 2007a). Category 2 sites were formed when the debris flow buried in situ the pre-existing thanatocoenoses. Therefore, in principle, debris-flow transport was not long. At monotaxic and multitaxic-monodominant debris-flow 
sites, remains belonging to the dominant taxon usually display homogeneous taphonomic features, because they have undergone the same taphonomic history. The monotaxic and multitaxic-monodominant assemblages at debris-flow sites in categories 1,2 and 4 reported at our Table 3 are generally the result of mass mortality events that occurred prior to entrainment by the debris flow (i.e., the debris flow is not the agent producing the mass mortality event).

We found only one example representative of category 3 (death caused by the debris flow) in the literature (Table 3). This corresponds to the exceptional Late Cretaceous fossil site of Ukhaa Tolgod (Mongolia). This vertebrate assemblage was entombed by the deposits of dune-sourced sandy mass flows that took place during rainstorms (Dashzeveg et al., 1995; Loope et al., 1998, 1999; Dingus et al., 2008). Although this site lacks a detailed taphonomic description, the taphonomic features reported for this assemblage generally fit well with what we expect to find in a site where death and burial of the biocoenosis were caused by the debris flow: abundance of articulated skeletons and minimal abrasion and weathering (Dashzeveg et al., 1995). Category 3 assemblages display the most homogeneous taphonomic features when compared to debris-flow sites in categories 1,2 and 4 .

Category 4 debris-flow assemblages are represented by the Jurassic site of Huizachal Canyon (Mexico) and the Pleistocene locality of Collecurti (Italy) (Table 3). In both cases, the localities comprise a mixture of assemblages that separately could be assigned to category 1 and category 2 debris-flow sites. At Huizachal Canyon, the presence of delicate specimens such as an articulated pterosaur would be indicative of in situ burials of thanacoenoses (Fastovsky et al., 1995). At the same time, the existence of highly fragmented and disarticulated specimens implies the reworking and burial of pre-existing thanatocoenoses by the debris-flow transport.

The Collecurti assemblage is made up of a combination of disarticulated, polished and weathered remains that belonged to diverse mammals, together with the skeletal elements of Hippopotamus antiquus which were found in close association and were practically unaffected by weathering or abrasion (Mazza and Ventra, 2011). The first assemblage (the disarticulated, weathered and polished assemblage) was exposed to different biostratinomic agents for some time at an upslope location and probably fluvially reworked. Subsequently, it was entrained by the debris flow and transported downslope, where it was mixed with the hippopotamus carcasses that were, in turn, buried in situ (Mazza and Ventra, 2011).

We agree with previous authors in that fossil remains found at debris-flow hosted assemblages display highly heterogeneous taphonomic features, sharing only a few consistent patterns (Britt et al., 2009; Scherzer and Varricchio, 2010). This heterogeneity is the consequence of several factors which include: 1) the death mode of the fauna, 2) the time of exposure and biostratinomic processes the remains were subjected to, 3) the time and distance of transport by the debris flow and 4) the lithological features of the debris flow.

Taphonomic studies provide insights into the mode of formation of assemblages, but also into the preservational biases and the paleoecological significance of the faunal association represented. Some depositional contexts show recurring taphonomic patterns but, as observed in this and previous studies, this is not true in the case of debris-flow assemblages. Detailed taphonomic analyses should be a priority at every fossil site regardless of its depositional context, but they become especially relevant at sites comprising a mixture of elements with differing taphonomic signatures and histories, such as debris-flow hosted assemblages.

\section{Conclusion}

In the present study, we conducted a detailed taphonomic analysis of the SOM-N Middle Miocene large-mammal assemblage to provide insights into the mode of formation and features of fossil sites formed in a debris-flow depositional context. Very few debris-flow sites are known in the Cenozoic. SOM-N joins Paşalar (Turkey) as the only two examples of Miocene age.

A total of 6592 large-mammal remains have been recovered at SOM$\mathrm{N}$. The fossils are embedded in matrix-supported and poorly-sorted coarse sandstones and fine conglomerates deposited by different debris-flow events. Intense breakage results in very high percentages of elements that cannot be assigned to a specific taxon or to a specific skeletal element (66.10\% and $49.23 \%$, respectively). Bones are found isolated which indicates that, prior to debris-flow transport, the carcasses were subaerially exposed for a sufficiently long time to enable disarticulation by decay, trampling or scavenging. Most of the bones display weathering stages 0 or 1 , which is indicative of a maximum exposure time of 3 years before burial, although the presence of bones showing weathering stages 2 and 3 indicates that some bones were exposed for longer time periods. Abraded bone surfaces and abraded bone fractures are abundant. Apart from splinters and bone clasts, which display extreme levels of breakage, there are also some relatively well preserved skeletal elements, which appear to evidence a shorter time of exposure and less alteration prior to and during debris-flow transport.

SOM-N belongs to category 1 debris-flow hosted assemblages in the classification proposed by Britt et al. (2009). Accordingly, the SOM-N assemblage is the result of debris-flow transport and burial of pre-existing thanacoenoses, where biostratinomic agents acted with different intensities. When compared with other debris-flow sites, SOM-N shares some sedimentological and taphonomic features mainly with other category 1 sites such as: the massive and poorly-sorted coarse-grained nature of the sediments, predominance of flat-lying fossil specimens, absence of preferential orientations in elongate elements, and abundance of isolated and heavily broken remains.

Supplementary data to this article can be found online at http://dx. doi.org/10.1016/j.palaeo.2016.10.023.

\section{Acknowledgements}

We wish to dedicate this work to the memory of Nieves López Martínez, who directed the works at the Somosaguas fossil sites for over a decade. We are especially indebted to Israel Polonio, Javier Elez and David Mínguez Gandú for their enthusiasm and entrepreneurial spirit as founders of the Somosaguas Palaeontology Project, as well as for their continuing interest in the results of our research of the Somosaguas fossil record. We also thank the members of the Somosaguas Paleontology Project and all the students and volunteers who have excavated at the Somosaguas sites. Carlos Alonso provided assistance with the photographs. We are grateful to Anna K. Behrensmeyer, Rodrigo Tomassini and Palaeo3 Editor, Thierry Corrège, for their valuable comments and suggestions. We wish to thank our Irish translator, Cormac De Brun, for the language revision of the manuscript. Recent excavations at Somosaguas sites have been funded by the Historical Heritage Section of the Madrid Community Regional Government and the Complutense University of Madrid. M.S.D. is a postdoctoral researcher of the Spanish MINECO Formación Postdoctoral 2013 program. L.D. is a Juan de la Cierva postdoctoral researcher funded by the Spanish MINECO. E.C. had a contract associated with the project CGL2009-09000 of the Spanish MINECO. J.L.C. is funded by the Alexander von Humboldt Foundation (Germany). This is a contribution by the Palaeoclimatology, Macroecology and Macroevolution of Vertebrates research team (www.pmmv.com.es) of the Complutense University of Madrid as a part of the Research Group UCM 910607 on Evolution of Cenozoic Mammals and Continental Palaeoenvironments.

\section{References}

Alberdi, M.T., 1985. Geología y Paleontología del Terciario continental de la Cuenca de Madrid. Museo Nacional de Ciencias Naturales-CSIC, Madrid.

Alcalá, L., 1994. Macromamíferos neógenos de la fosa de Alfambra-Teruel. Instituto de Estudios Turolenses, Teruel. 
Alonso-Zarza, A.M., Calvo, J.P., Silva, P.G., Torres, T., 2004. Cuenca del Tajo. In: Vera, J.A. (Ed.), Geología de España. SGE-IGME, Madrid, pp. 556-561.

Andrews, P., 1995. Time resolution of the Miocene fauna from Paşalar. J. Hum. Evol. 28: 343-358. http://dx.doi.org/10.1006/jhev.1995.1027.

Andrews, P., Armour-Chelu, M., 1998. Taphonomic observations on a surface bone assemblage in a temperate environment. Bull. Soc. Geol. Fr. 169, 433-442.

Andrews, P., Ersoy, A., 1990. Taphonomy of the Miocene bone accumulations at Paşalar, Turkey. J. Hum. Evol. 19:379-396. http://dx.doi.org/10.1016/0047-2484(90)90051-C.

Ansón, M., 2013. Nuevos datos sobre Anchitherium von Meyer, 1834 del Mioceno medio de Somosaguas (Pozuelo de Alarcón, Madrid). Universidad Autónoma de Barcelona, MSc. Thesis.

Araújo-Júnior, H.I., Oliveira Porpino, K., Lira Ximenes, C., Paglarelli Bergqvist, L., 2013. Unveiling the taphonomy of elusive natural tank deposits: a study case in the Pleistocene of northeastern Brazil. Palaeogeogr. Palaeoclimatol. Palaeoecol. 378:52-74. http://dx.doi.org/10.1016/j.palaeo.2013.04.001.

Badgley, C., 1986. Counting individuals in mammalian fossil assemblages from fluvial environments. PALAIOS 1:328-338. http://dx.doi.org/10.2307/3514695.

Behrensmeyer, A.K., 1978. Taphonomic and ecologic information from bone weathering. Paleobiology 4, 150-162.

Behrensmeyer, A.K., 1982. Time resolution in fluvial vertebrate assemblages. Paleobiology 8, 211-227.

Behrensmeyer, A.K., 1991. Terrestrial vertebrate accumulations. In: Allison, P.A., Briggs, D.E.G. (Eds.), Taphonomy: Releasing the Data Locked in the Fossil Record. Plenum Press, New York, pp. 291-335.

Behrensmeyer, A.K., Hook, R.W., 1992. Paleoenvironment contexts and taphonomic modes. In: Behrensmeyer, A.K., Damuth, J.D., DiMichele, W.A., Potts, R., Sues, H.-D., Wing, S.L. (Eds.), Terrestrial Ecosystems through Time. The University of Chicago Press, Chicago, pp. 15-136.

Behrensmeyer, A.K., Gordon, K.D., Yanagi, G.T., 1986. Trampling as a cause of bone surface damage and pseudo-cutmarks. Nature 319, 768-771.

Behrensmeyer, A.K., Gordon, K.D., Yanagi, G.T., 1989. Nonhuman bone modification in Miocene fossils from Pakistan. In: Bonnichsen, R., Sorg, M.H. (Eds.), Bone Modification. Center for the study of the first Americans, Institute for Quaternary studies, University of Maine, Orono, pp. 99-120.

Benítez-López, G., Fesharaki, O., Gómez Cano, A.R., Pérez de los Ríos, M., 2009. Equipo de Introducción a la Investigación GeoPaleoBiológica en Somosaguas: un nuevo enfoque para el aprendizaje de la investigación. Paleolusitana 1, 105-113.

Blanco, F., Hernández Fernández, M., 2016. Heterogeneidad lateral en las muestras de roedores del tramo T1 del Mioceno medio de Somosaguas (Pozuelo de Alarcón, Madrid). Estud. Geol. 72:e052. http://dx.doi.org/10.3989/egeol.42255.386.

Britt, B.B., Eberth, D.A., Scheetz, R.D., Greenhalgh, B.W., Stadtman, K.L., 2009. Taphonomy of debris-flow hosted dinosaur bonebeds at Dalton Wells, Utah (Lower Cretaceous, Cedar Mountain Formation, USA). Palaeogeogr. Palaeoclimatol. Palaeoecol. 280: 1-22. http://dx.doi.org/10.1016/j.palaeo.2009.06.004.

Calvo, J.P., Alonso-Zarza, A.M., García del Cura, M.A., 1989. Models of Miocene marginal lacustrine sedimentation in response to varied depositional regimes and source areas in the Madrid Basin (Central Spain). Palaeogeogr. Palaeoclimatol. Palaeoecol. 70, 199-214.

Carrasco, A., Sacristán, S., Benítez-López, G., Romero-Nieto, D., Fesharaki, O., LópezMartínez, N., 2008. Aplicaciones paleoclimáticas y paleoambientales de los estudios mineralógicos al yacimiento de vertebrados miocenos de Somosaguas. Palaeontol. Nova 8, 135-149.

Castilla, G., Fesharaki, O., Hernández Fernández, M., Montesinos, R., Cuevas-González, J., López Martínez, N., 2006. Experiencias educativas en el yacimiento paleontológico de Somosaguas (Pozuelo de Alarcón, Madrid). Enseñanza Cienc. Tierra 14, 265-270.

Corona, A., Perea, D., Toriño, P., Goso, C., 2012. Taphonomy, sedimentology and chronology of a fossiliferous outcrop from the continental Pleistocene of Uruguay. Rev. Mex. Cienc. Geol. 29, 514-525.

Cuevas-González, J., 2005. Estado actual de los conocimientos paleontológicos y estratigráficos de los yacimientos aragonienses de Somosaguas (Pozuelo de Alarcón, Madrid). Coloquios Paleontol. 55, 103-123.

Cuezva, S., Elez, J., 2000. Reconocimiento del estadio de desarrollo en la microestructura de los huesos fósiles de mamíferos (Somosaguas y Layna). Coloquios Paleontol. 51, 159-174.

Daams, R., van der Meulen, A.J., Álvarez Sierra, M.A., Peláez-Campomanes, P., Krijgsman, W., 1999. Aragonian stratigraphy reconsidered, and a re-evaluation of the middle Miocene mammal biochronology in Europe. Earth Planet. Sci. Lett. 165, 287-294.

Dashzeveg, D., Novacek, M.J., Norell, M.A., Clark, J.M., Chiappe, L.M., Davidson, A., McKenna, M.C., Dingus, L., Swisher, C., Altangerel, P., 1995. Extraordinary preservation in a new vertebrate assemblage from the Late Cretaceous of Mongolia. Nature 374:446-449. http://dx.doi.org/10.1038/374446a0.

Díez-Canseco, D., López-Martínez, N., Díaz-Molina, M., Benito, M.I., 2012. Stream mouth deposits in the palaeontological site of Somosaguas, Middle Miocene, Madrid Basin. Span. J. Paleontol. 27, 93-104.

Dingus, L., Loope, D.B., Dashzeveg, D., Swisher III, C.C., Minjin, C., Novacek, M.J., Norell, M.A., 2008. The geology of Ukhaa Tolgod (Djadokhta Formation, Upper Cretaceous, Nemegt Basin, Mongolia). Am. Mus. Novit. 3616, 1-40.

Domingo, L., Cuevas-González, J., Grimes, S.T. Hernández Fernández, M., López-Martínez, N., 2009. Multiproxy reconstruction of the palaeoclimate and palaeoenvironment of the Middle Miocene Somosaguas site (Madrid, Spain) using herbivore dental enamel. Palaeogeogr. Palaeoclimatol. Palaeoecol. 272:53-68. http://dx.doi.org/10.1016/j. palaeo.2008.11.006.

Domingo, L., Koch, P.L., Grimes, S.T., Morales, J., López-Martínez, N., 2012a. Isotopic paleoecology of mammals and the Middle Miocene cooling event in the Madrid Basin (Spain). Palaeogeogr. Palaeoclimatol. Palaeoecol. 339-341:98-113. http://dx.doi.org/ 10.1016/j.palaeo.2012.04.026.
Domingo, L., López-Martínez, N., Grimes, S.T., 2012b. Trace element analyses indicative of paleodiets in Middle Miocene mammals from the Somosaguas site (Madrid, Spain). Geol. Acta 10:239-247. http://dx.doi.org/10.1344/105.000001746.

Domingo, M.S., Sánchez, I.M., Alberdi, M.T., Azanza, B., Morales, J., 2012. Evidence of predation/scavenging on Moschidae (Mammalia, Ruminantia) from the Late Miocene of Spain. Lethaia $45,386-400$.

Domingo, M.S., Alberdi, M.T., Azanza, B., Silva, P.G., Morales, J., 2013. Origin of an assemblage massively dominated by carnivorans from the Miocene of Spain. PLoS One 8, e63046.

Eberth, D.A., Britt, B.B., Scheetz, R., Stadtman, K.L., Brinkman, D.B., 2006. Dalton wells: geology and significance of debris-flow-hosted dinosaur bonebeds in the Cedar Mountain Formation (Lower Cretaceous) of eastern Utah, USA. Palaeogeogr. Palaeoclimatol. Palaeoecol. 236:217-245. http://dx.doi.org/10.1016/j.palaeo.2005.11.020.

Eberth, D.A., Rogers, R.R., Fiorillo, A.R., 2007a. A practical approach to the study of bonebeds. In: Rogers, R.R., Eberth, D.A., Fiorillo, A.R. (Eds.), Bonebeds: Genesis, Analysis, and Paleobiological Significance. The University of Chicago Press, Chicago, pp. 265-331.

Eberth, D.A., Shannon, M., Noland, B.G., 2007b. A bonebeds database: classification, biases, and patterns of occurrence. In: Rogers, R.R., Eberth, D.A., Fiorillo, A.R. (Eds.) Bonebeds: Genesis, analysis and paleobiological significance. The University of Chicago Press, Chicago, pp. 103-219.

Elez,J., 2005. Aplicación GIS 3D a los yacimientos paleontológicos de Somosaguas Unpublished Advanced Studies Diploma, Universidad Complutense de Madrid.

Evans, D.C., Eberth, D.A., Ryan, M.J., 2015. Hadrosaurid (Edmontosaurus) bonebeds from the Horseshoe Canyon Formation (Horsethief member) at Drumheller, Alberta, Canada: geology, preliminary taphonomy, and significance. Can. J. Earth Sci. 52:642-654. http://dx.doi.org/10.1139/cjes-2014-0184.

Fastovsky, D.E., Clark, J.M., Strater, N.H., Montellano, M., Hernández, R., Hopson, J.A., 1995 Depositional environments of a Middle Jurassic terrestrial vertebrate assemblage, Huizachal Canyon, Mexico. J. Vertebr. Paleontol. 15, 561-575.

Fesharaki, O., 2016. Análisis paleoambiental y paleoclimático de los yacimientos de Somosaguas y Húmera (Mioceno medio, Madrid): Sedimentología, petrología, mineralogía y aplicación a divulgación e innovación educativa. (Ph.D. Dissertation). Universidad Complutense de Madrid.

Fesharaki, O., García-Romero, E., Cuevas-González, J., López-Martínez, N., 2007. Clay mineral genesis and chemical evolution in the Miocene sediments of Somosaguas, Madrid Basin, Spain. Clay Miner. 42:187-201. http://dx.doi.org/10.1180/claymin.2007. 042.2.05.

Fesharaki, O., Torices, A., García Yelo, B.A., Tejedor-Navarro, N., de la Ossa, L., Hernández Fernández, M. 2012. The Somosaguas Palaeontology project: an envision of Nieves López Martínez for linking science and society. Span. J. Palaeontol. 27, 83-92.

Fesharaki, O., Arribas, J., López-Martínez, N., 2015. Composition of clastic sediments in the Somosaguas area (middle Miocene, Madrid Basin): insights into provenance and palaeoclimate. J. Iber. Geol. 41:205-222. http://dx.doi.org/10.5209/rev_JIGE.2015. v41.n2.44802.

Flower, B.P., Kennett, J.P., 1994. The Middle Miocene climatic transition: East Antarctic ice sheet development, deep ocean circulation and global carbon cycling Palaeogeogr. Palaeoclimatol. Palaeoecol. 108:537-555. http://dx.doi.org/10.1016/00310182(94)90251-8.

García Yelo, B.A., Gómez Cano, A.R., Cantalapiedra, J.L., Alcalde, G.M., Sanisidro, O., Oliver, A., Hernández-Ballarín, V., López-Guerrero, P., Fraile, S., Hernández Fernández, M., 2014. Palaeoenvironmental analysis of the Aragonian (middle Miocene) mammalian faunas from the Madrid Basin based on body-size structure. J. Iber. Geol. 40:129-140. http://dx.doi.org/10.5209/rev_JIGE.2014.v40.n1. 44092.

Garrido, A.C., Salgado, L., 2015. Taphonomy and depositional environment of a Lower Cretaceous monospecific dinosaur bone assemblage (Puesto Ouiroga Member, Lohan cura Formation), Neuquén Province, Argentina. J. S. Am. Earth Sci. 61:53-61. http:// dx.doi.org/10.1016/j.jsames.2015.03.008.

Hernández Fernández, M., Salesa, M.J., Sánchez, I.M., Morales, J., 2003. Paleoecología del género Anchitherium von Meyer, 1834 (Equidae, Perissodactyla, Mammalia) en España: evidencias a partir de las faunas de macromamíferos. Coloquios Paleontol. $1,253-280$.

Hernández Fernández, M., Cárdaba, J.A., Cuevas-González, J., Fesharaki, O., Salesa, M.J. Corrales, B., Domingo, L., Elez, J., López-Guerrero, P., Sala-Burgos, N., Morales, J., López-Martínez, N., 2006. Los yacimientos de vertebrados del Mioceno medio de Somosaguas (Pozuelo de Alarcón, Madrid): implicaciones paleoambientales y paleoclimáticas. Estud. Geol. 62, 263-294.

Hernández-Ballarín, V., Oliver, A., Peláez-Campomanes, P., 2011. Revisión de las asociaciones de mamíferos del tránsito Aragoniense medio y superior de la cuenca de Madrid. In: Pérez-García, A., Gascó, F., Gasulla, J.M., Escaso, F. (Eds.), Viajando a Mundos Pretéritos. Ajuntament de Morella, pp. 173-182.

Hill, A., Behrensmeyer, A.K., 1984. Disarticulation patterns of some modern East African mammals. Paleobiology 10, 366-376.

Hoyos, M., Junco, F., Plaza, J.M., Ramírez, A., Ruiz Sánchez-Porro, J., 1985. El Mioceno de Madrid. In: Alberdi, M.T. (Ed.), Geología y Paleontología del Terciario Continental de la Provincia de Madrid. Museo Nacional de Ciencias Naturales-CSIC, Madrid, pp. 9-16.

Lauters, P., Bolotsky, Y.L., van Itterbeeck, J., Godefroit, P., 2008. Taphonomy and age profile of a latest Cretaceous dinosaur bone bed in Far Eastern Russia. PALAIOS 23:153-162. http://dx.doi.org/10.2110/palo.2006.p06-031r.

Lewis, A.R., Marchant, D.R., Ashworth, A.C., Hedenäs, L., Hemming, S.R., Johnson, J.V., Leng, M.J., Machlus, M.L., Newton, A.E., Raine, J.I., Willenbring, J.K., Williams, M., Wolfe, A.P., 2008. Mid-Miocene cooling and the extinction of tundra in continental Antarctica. Proc. Natl. Acad. Sci. 105:10676-10680. http://dx.doi.org/10. 1073/pnas.0802501105. 
Loope, D.B., Dingus, L., Swisher III, C.C., Minjin, C., 1998. Life and death in a Late Cretaceous dune field, Nemegt basin, Mongolia. Geology 26:27-30. http://dx.doi.org/10.1130/ 0091-7613(1998)026<0027:LADIAL >2.3.CO;2.

Loope, D.B., Mason, J.A., Dingus, L., 1999. Lethal sandslides from eolian dunes. J. Geol. 107: 707-713. http://dx.doi.org/10.1086/314377.

López-Martínez, N., Elez Villar, J., Hernando Hernando, J.M., Luis Cavia, A., Mazo, A., Mínguez Gandú, D., Morales, J., Polonio Martín, I., Salesa, M.J., Sánchez, I.M., 2000. Los fósiles de vertebrados de Somosaguas (Pozuelo, Madrid). Coloquios Paleontol. $51,71-85$.

Lovelace, D.M., 2006. An Upper Jurassic Morrison Formation fire-induced debris flow: taphonomy and paleoenvironment of a sauropod (Sauropoda: Supersaurus vivianae) locality, East-Central Wyoming. In: Foster, J.R., Lucas, S.G. (Eds.), Paleontology and Geology of the Upper Jurassic Morrison Formation. New Mexico Museum of Natural History and Science Bulletin Vol. 36, pp. 47-56.

Luis, A., Hernando, J.M., 2000. Los microvertebrados del Mioceno Medio de Somosaguas Sur (Pozuelo de Alarcón, Madrid, Spain). Coloquios Paleontol. 51, 87-136.

Lyman, R.L., 1994. Vertebrate Taphonomy. Cambridge University Press, Cambridge.

Madurell-Malapeira, J., Alba, D.M., Aurell-Garrido, P., Moyà-Solà, S., 2011. Taphonomic approach to the last Villafranchian faunas of Europe: the layer 7 of the Vallparadís Estació local section (Vallès-Penedès Basin, NE Iberian Peninsula). IX Encuentro de Jóvenes Investigadores en Paleontología, Morella (Castellón). Proceedings Volume, pp. 203-210.

Mazo, A., 2000. Presencia de Gomphotherium angustidens (Cuvier) (Proboscidea, Mammalia) en el yacimiento de Somosaguas (Pozuelo de Alarcón, Madrid). Coloquios Paleontol. 51, 175-181.

Mazza, P.P.A., Ventra, D., 2011. Pleistocene debris-flow deposition of the hippopotamusbearing Collecurti bonebed (Macerata, Central Italy): taphonomic and paleoenvironmental analysis. Palaeogeogr. Palaeoclimatol. Palaeoecol. 310:296-314. http://dx.doi.org/10.1016/j.palaeo.2011.07.022.

Mein, P., 1975. Résultats du groupe de travail des vertébrés: biozonation du Néogène méditerranéen à partir des mammifères. In: Senes, J. (Ed.), Report on Activity of the Regional Committee on Mediterranean Neogene Stratigraphy, Bratislava, pp. 77-81.

Menéndez, I., Gómez Cano, A.R., Hernández Fernández, M., 2015. Patrón de mortandad de Megacricetodon collongensis (MEIN, 1958) en Somosaguas Sur (Mioceno Medio, Pozuelo de Alarcón, Madrid). In: Domingo, L., Domingo, M.S., Fesharaki, O., García Yelo, B.A., Gómez Cano, A.R., Hernández-Ballarín, V., Hontecillas, D., Cantalapiedra, J.L., López Guerrero, P., Oliver, A., Pelegrín, J. (Eds.), Current Trends in Paleontology and Evolution, XIII EJIP. Conference Proceedings, Madrid, pp. 188-190.

Miller, J., Druckenmiller, P., Bahn, V., 2013. Antlers on the Arctic Refuge: capturing multigenerational patterns of calving ground use from bones on the landscape. Proc. R. Soc. B 280, 20130275.

Mínguez Gandú, D., 2000. Marco estratigráfico y sedimentológico de los yacimientos paleontológicos miocenos de Somosaguas (Madrid, España). Coloquios Paleontol. 51, 183-195.

Morales, J. (Coord.), 2000. Patrimonio Paleontológico de la Comunidad de Madrid Comunidad de Madrid, Madrid.

Myers, T.S., Storrs, G.W., 2007. Taphonomy of the Mother's Day quarry, Upper Jurassic Morrison Formation, South-Central Montana, USA. PALAIOS 22:651-666. http://dx doi.org/10.2110/palo.2005.p05-123r.

Peláez-Campomanes, P., Morales, J., Álvarez Sierra, M.A., Azanza, B., Fraile, S., García Paredes, I., Hernández Fernández, M., Herráez, E., Nieto, M., Pérez, B., Quiralte, V., Salesa, M.J., Sánchez, I.M., Soria, D., 2003. Updated biochronology of the Miocene mammal faunas from the Madrid Basin (Spain). In: Reumer, J.W.F., Wessels, W. (Eds.), Distribution and Migration of Tertiary Mammals in Eurasia. A volume in honour of Hans de Bruijn. DEINSEA Vol. 10, pp. 431-441.
Perales, R., Serrano, H. García Yelo, B.A., Hernández Fernández, M., 2009. Inferencias paleoambientales del Mioceno medio de Somosaguas (Pozuelo de Alarcón, Madrid) basadas en la estructura de tamaños corporales de su fauna de mamíferos. Paleolusitana 1, 317-325.

Pérez-García, A., 2013. Turtles from the middle Miocene (MN5) of Somosaguas (Pozuelo de Alarcón, Madrid, Spain). Span. J. Paleontol. 28, 55-60.

Pesquero, M.D., Alcalá, L., Fernández-Jalvo, Y., 2013. Taphonomy of the reference Miocene vertebrate mammal site of Cerro de la Garita, Spain. Lethaia 46:378-398. http://dx. doi.org/10.1111/let.12016.

Pickford, M., Laurent, Y., 2014. Valorisation of palaeontological collections: nomination of a lectotype for Conohyus simorrensis (Lartet, 1851), Villefranche d'Astarac, France, and description of a new genus of tetraconodont. Estud. Geol. 70:e002. http://dx.doi.org/ 10.3989/egeol.41261.262.

Pina, M., Pérez de los Ríos, M., Hernández Fernández, M., 2008. Paleocorología de los mamíferos del Mioceno medio de Somosaguas (Pozuelo de Alarcón, Madrid). Semin. Paleontol. Zaragoza 8, 345-356.

Polonio, I., López-Martínez, N., 2000. Análisis tafonómico de los yacimientos de Somosaguas (Mioceno medio, Madrid). Coloquios Palentol. 51, 235-265.

Salesa, M.J., Morales, J., 2000. La fauna de carnívoros del yacimiento aragoniense de Somosaguas (Pozuelo de Alarcón, Madrid). Coloquios Paleontol. 51, 213-222.

Salesa, M.J., Sánchez, I.M., 2000. Estudio de los restos de Anchitherium Meyer 1834 del yacimiento de Somosaguas (Pozuelo de Alarcón, Madrid). Coloquios Paleontol. 51, 197-211.

Sánchez, I.M., 2000. Los rumiantes (Mammalia, Artiodactyla) del yacimiento de Somosaguas (Aragoniense medio-superior, Madrid). Coloquios Paleontol. 51, 223-234.

Scherzer, B.A., Varricchio, D.J., 2010. Taphonomy of a juvenile lambeosaurine bonebed from the Two Medicine Formation (Campanian) of Montana, United States. PALAIOS 25:780-795. http://dx.doi.org/10.2110/palo.2009.p09-143r.

Storrs, G.W., Oser, S.E., Aull, M., 2013. Further analysis of a Late Jurassic dinosaur bone-bed from the Morrison Formation of Montana, USA, with a computed three dimensional reconstruction. Earth Environ. Sci. Trans. R. Soc. Edinb. 103:443-458. http://dx.doi. org $/ 10.1017 / \mathrm{S} 1755691013000248$.

Torroba, J., Gómez de la Peña, L., Gómez Cano, A.R., López Guerrero, P., Hernández Fernández, M., 2010. Estudio de los patrones de mortandad de Democricetodon larteti (Schaub, 1925) en el yacimiento mioceno de Somosaguas (Pozuelo de Alarcón, Madrid). Cidaris 30, 325-328.

Trabada Guijarro, J., González Jiménez, A., Díaz Retana, J.M., Herrera Álvarez, M., Rodríguez Rodríguez, V. (Coord.), 2006. El Patrimonio Arqueológico y Paleontológico en las Obras de Ampliación de Metro de Madrid, 2003-2007. Comunidad de Madrid, Madrid.

van der Made, J., Salesa, M.J., 2004. Early remains of the pig Conohyus simorrensis from the Middle Aragonian of Somosaguas near Madrid - its dispersal into Europe and evolution. Neues Jahrb. Geol. Paläontol. Abh. 233, 153-168.

van Itterbeeck, J., Bolotsky, Y., Bultynck, P., Godefroit, P., 2005. Stratigraphy, sedimentology and palaeocology of the dinosaur-bearing Kundur section (Zeya-Bureya Basin, Amur Region, Far Eastern Russia). Geol. Mag. 142:735-750. http://dx.doi.org/10. 1017/S0016756805001226.

Voorhies, M.R., 1969. Taphonomy and population dynamics of an early Pliocene vertebrate fauna, Knox County, Nebraska. Contributions to Geology, University of Wyoming Special Paper Vol. 1, pp. 1-69.

Zachos, J., Pagani, M., Sloan, L., Thomas, E., Billups, K., 2001. Trends, rhythms, and aberrations in global climate 65 Ma to present. Science 292:686-693. http://dx.doi.org/10. 1126/science. 1059412.

Zingg, T., 1935. Beitrag zur schotteranalyse. Schweizi. Mineral. Petrogr. Mitt. 15, 39-140. 